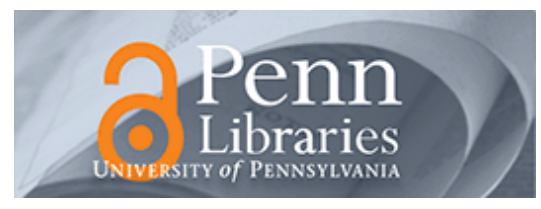

University of Pennsylvania

ScholarlyCommons

Real Estate Papers

Wharton Faculty Research

7-2015

\title{
Evaluating Seasonal Food Storage and Credit Programs in East Indonesia
}

Karna Basu

Maisy Wong

University of Pennsylvania

Follow this and additional works at: https://repository.upenn.edu/real-estate_papers

Part of the Growth and Development Commons, and the Real Estate Commons

\section{Recommended Citation}

Basu, K., \& Wong, M. (2015). Evaluating Seasonal Food Storage and Credit Programs in East Indonesia. Journal of Development Economics, 115 200-216. http://dx.doi.org/10.1016/j.jdeveco.2015.02.001

This paper is posted at ScholarlyCommons. https://repository.upenn.edu/real-estate_papers/6

For more information, please contact repository@pobox.upenn.edu. 


\title{
Evaluating Seasonal Food Storage and Credit Programs in East Indonesia
}

\begin{abstract}
Predictable annual lean seasons occur in many rural areas, including West Timor in Indonesia. Imperfections in savings and credit markets make it difficult for staple farmers to convert harvest season output into lean season consumption. We conduct a randomized evaluation of a seasonal food storage program and a food credit program. By providing improved ways to transfer assets across seasons, each program functions as a subsidy on lean season consumption. We find that neither program had effects on staple food consumption. The storage program increased non-food consumption. The credit program increased reported income and reduced seasonal gaps in consumption. Our results are consistent with positive income effects through the expansion of budget sets, but suggest that the average household could be close to staple food satiation.
\end{abstract}

Keywords

seasonality, food policy, food storage, food credit

Disciplines

Economics | Growth and Development | Real Estate 


\title{
Evaluating Seasonal Food Security Programs in East Indonesia
}

\author{
Karna Basu* and Maisy Wong $^{\dagger}$
}

February 26, 2014

\begin{abstract}
Predictable annual lean seasons occur in many rural areas, including West Timor in Indonesia. Staple farmers there who face seasonal savings and credit constraints have difficulty converting harvest season output to lean season consumption. We conduct a randomized evaluation of a seasonal food credit program and a food storage program designed to alleviate seasonal frictions which result from these constraints. By providing improved ways to transfer assets across seasons, each program potentially functions as a subsidy on lean season consumption. The programs increased non-food consumption and reported income, but had precise zero effects on staple food consumption. Our results are consistent with positive income effects through the expansion of budget sets, but suggest that the average household could be close to staple food satiation.
\end{abstract}

Keywords: Seasonality, Hunger, Food Security, Food policy

\footnotetext{
${ }^{*}$ Corresponding author. Email: kbasu@ hunter.cuny.edu; Phone: 1-212-396-6521; Address: Department of Economics, Hunter College, City University of New York, 695 Park Ave, New York, NY 10065.

†Email: maisy@wharton.upenn.edu; Address: 3620 Locust Walk, 1464 SHDH, Wharton Real Estate, University of Pennsylvania, Philadelphia PA 19104-6302.
} 


\section{Introduction}

The Food and Agricultural Organization estimates that 868 million people are malnourished globally (FAO, 2013). Seasonal food shortages are evident in many rural areas. ${ }^{1}$ Predictable annual hunger seasons can arise when incomes vary by season and households face savings and credit constraints. ${ }^{2}$ However, seasonality is an understudied aspect of food security and there is limited evidence on the impacts of programs that alleviate seasonal savings and credit constraints. ${ }^{3}$

We conducted a randomized evaluation of two food programs-food storage and food credit-that target savings and credit constraints related to seasonal food shortages in West Timor. This island in East Indonesia has historically suffered from an annual lean season known as musim paceklik. Many subsistence farmers rely on rain-fed agriculture, have difficulty borrowing against future harvests, use rudimentary food storage technologies with low retention rates, and face seasonal price variation.

We build a stylized model to show how the above features limit households' ability to convert harvest season agricultural output into lean season consumption. Absent seasonal credit and savings constraints, the harvest-to-lean season marginal rate of transformation (MRT) of food would be equal to one. In contrast, farmers in West Timor face what we call seasonal frictions-an MRT of less than one. Our food credit and food storage programs can raise the MRT by introducing new ways for farmers to transfer assets across seasons.

In 2008, we randomly assigned 96 villages to receive a food storage program, a food credit program, or no program. The storage program offered households free staple food storage equipment-weather-sealed drums and sacks-with high retention rates. For credit, women's microcredit groups were formed and offered loans of staples (rice and maize) during the lean season, which were to be repaid in kind during the following harvest. Repaid grain was stored in sealed facilities for disbursement in the following lean season. The programs had the potential to raise the harvest-to-lean MRT by either improving the food retention rate or allowing households to borrow against future harvests relatively cheaply.

Intuitively, the lower a household's harvest-to-lean MRT, the more food it must

\footnotetext{
${ }^{1}$ Seasonal food shortages have been documented in parts of Sub-Saharan Africa, South Asia and Southeast Asia. See Khandker and Mahmud (2012) and Devereux, Sabates-Wheeler, and Longhurst (2012) for an overview.

${ }^{2}$ There is a large literature on the challenges to consumption smoothing in the presence of credit or savings constraints, notably Deaton (1991) and Townsend (1994). See Khandker and Mahmud (2012) for a discussion focused on seasonality and Zeller et al. (1997) for an overview that relates food security policies to the consumption smoothing literature.

${ }^{3}$ Seasonal food deprivation has been described as the "cycle of quiet starvation" and the "father of famine" (Devereux, Vaitla, and Swan, 2008) and "one of the most persistent and intractable aspects of global food insecurity" (Khandker and Mahmud, 2012). Yet, according to two surveys on this topic, "[o]f all the dimensions of rural deprivation, the most neglected is seasonality" (Devereux, Vaitla, and Swan, 2008), and, "[a] focus on seasonality is often missing" in social protection schemes (Khandker and Mahmud, 2012). There is a small but growing literature on policies to mitigate seasonal food shortages. We discuss this later in the introduction.
} 
forego in any harvest to provide for a unit of lean season consumption. Seasonal frictions therefore imply a high opportunity cost of lean season consumption. The programs, by raising the MRT, effectively serve as lean season subsidies. As a result, households' inter-seasonal budget sets should expand, changing consumption patterns through income and substitution effects.

To investigate the impacts of these seasonal food policies, we built a large scale seasonal household panel that tracked 2,870 households during each harvest and lean season over three years. We test for treatment effects using four categories of wellbeing: consumption and income levels, seasonal differences in consumption and income, indicators of food shortages, and self-reported health.

Strikingly, both programs had fairly precise zero effects on staple food consumption in spite of our focus on raising the MRT of staple foods. However, we find sizeable impacts along other consumption and income margins. For storage, monthly per capita non-food consumption increased by $32.4 \%$. For credit, monthly per capita reported income increased by $54.3 \%$ with no detectable drops in consumption levels. ${ }^{4}$ Both patterns are consistent with positive income effects through budget set expansions for treated households.

Additionally, under credit, the seasonal gap in monthly non-food expenditure items narrowed by $16 \%$, but there were moderately negative health effects in the harvest season. $^{5}$ In Sections 3 and 4, we highlight differences between the credit and storage treatments that could explain why storage has positive effects on consumption but none on seasonal differences, while credit has effects on both. In particular, the credit program contains features that are arguably better at protecting households against risk.

Our paper relates to the literature on food policy in developing countries, ${ }^{6}$ and to the literature on consumption seasonality. ${ }^{7}$ Angelucci and Attanasio (2013) and Attanasio, Battistin, and Mesnard (2012) find positive effects of conditional transfers on food consumption for poor urban households in Mexico and for urban and rural households in Colombia. Hidrobo et al. (2014) find that food transfers, food vouchers and cash transfers in urban centers in Ecuador significantly improved the quantity and quality of food consumed. These programs are relatively less comparable to ours as the cash

\footnotetext{
${ }^{4}$ For credit, the effect on non-food consumption is $12 \%$ but is not statistically significant. For storage, the effect on reported income is $51.5 \%$ but is not statistically significant.

${ }^{5}$ The health effects are statistically insignificant when we pool both seasons. For storage, we find relatively precise zero effects on both health and seasonal differences. Both treatments had statistically insignificant effects on food shortages.

${ }^{6}$ See Barrett (2002), Dréze, Sen, and Hussain (1995) and Zeller, Schrieder, von Braun, and Heidhues (1997) for an overview of the literature on food policies. There is a long literature investigating the targeting properties and treatment effects of food policies, especially food price subsidies (see, for example, Besley and Kanbur (1990) and Jha and Ramaswami (2010)).

${ }^{7}$ There is a smaller but growing literature on consumption smoothing across seasons within an agricultural cycle. See, for example, Sahn (1989); Paxson (1993); Alderman and Garcia (1993); Handa and Mlay (2006); Chaudhuri and Paxson (2002); Alderman and Sahn (1989); Behrman (1988); PinstrupAnderson and Jaramillo (1989); Khandker (2012). More recently, there have been some randomized controlled trials related to consumption seasonality (Bryan, Chowdhury, and Mobarak (2013); Beaman, Karlan, and Thuysbaert (2009)).
} 
transfers were conditional and, in the case of Hidrobo et al. (2014), included a nutrition sensitization component. Our results are closer to those of Jensen and Miller (2011), who find no evidence that price subsidies (in the form of food vouchers for staples) improved nutrition for poor urban households in two provinces in China.

Our large effects on non-food consumption and reported income, with zero effects on staple consumption, suggest that the average household in our study could be close to staple food satiation. This is consistent with preferences where the marginal utility of staples drops rapidly relative to the marginal utility of other consumption (see Banerjee and Duflo (2007) and Jensen and Miller (2008) for related discussions of preferences).

This finding is particularly salient if we consider transaction costs associated with the buying and selling of food, which are likely to be significant given our focus on remote rural households. Under standard food subsidy programs, transaction costs of converting cash (or vouchers) to staples might incentivize households against raising staple consumption. In contrast, our programs directly expand in-kind income, so households minimize transaction costs by raising staple consumption instead of converting it to other goods. ${ }^{8}$ Yet, we find fairly precise zero staple effects. This has important policy implications because staples play a central role in many food programs in developing countries. ${ }^{9}$

While our programs generate subsidy-like income and substitution effects, the mechanisms are different from standard price subsidies. Our programs subsidize lean season consumption by introducing new products aimed at sources of seasonal frictions (poor storage methods and high interest costs for lean season consumption). By raising the MRT of staples as assets that can be both traded and consumed in the lean season, the programs subsidize not just lean season staples but all lean season consumption.

The food storage and food credit programs can therefore be viewed as compelling alternate ways to address seasonal frictions. Other approaches to the problem have been examined in a number of studies. Khandker, Khaleque, and Samad (2011) find that government social safety nets reduce both seasonal and non-seasonal insecurity to a limited extent. As ways to mitigate problems of seasonal famine, Pitt and Khandker (2002) and Khandker, Khalily, and Samad (2010) study cash-based credit programs and Bryan, Chowdhury, and Mobarak (2013) study seasonal migration.

Our cost-benefit calculations suggest that our programs are cost-effective interventions. By targeting the sources of seasonal frictions, the programs can persistently improve the rate at which farmers transfer assets across seasons. We confirm that the benefits appear to be sustainable using multiple post-treatment surveys. Since the upfront fixed costs (to purchase storage equipment and seed capital for credit) can be amortized over time, persistent benefits raise the implied cost-effectiveness of the programs. $^{10}$

\footnotetext{
${ }^{8}$ As discussed in Ahmed, Quisumbing, Nasreen, Hoddinott, and Bryan (2010), transaction costs are an important determinant of the impacts of in-kind or cash transfers on food consumption.

${ }^{9}$ In the Philippines, the rice subsidy program accounts for $70 \%$ of public social protection expenditures (Jha and Ramaswami, 2010). Indonesia and India too have large and expensive staple subsidy programs.

${ }^{10}$ By contrast, standard in-kind and cash transfers and direct food subsidy programs incur per period,
} 
We provide some background on West Timor in Section 2, present the theoretical framework in Section 3, describe the treatments in Section 4, discuss data in Section 5, lay out the empirical framework in Section 6, discuss results in Section 7, and conclude in Section 8.

\section{Background}

West Timor occupies half of the island of Timor. It is in one of Indonesia's poorest provinces, where $23 \%$ of rural households in this province live in poverty, compared to $14 \%$ for Indonesia (BPS, 2013). Our study focuses on smallholder staple farmers, many of whom are dependent on rain-fed agriculture. ${ }^{11}$ In our sample, $93 \%$ of household heads reported they were self-employed in the past week and $81 \%$ reported farming as their primary occupation. The climate is characterized by a brief monsoon (typically between November and January) followed by a long dry spell. While rice is the primary staple across Indonesia, maize has traditionally been the primary staple consumed in West Timor. ${ }^{12}$ Maize is also the primary crop grown in West Timor, followed by rice. ${ }^{13}$ The main harvest seasons occur in April for maize and May-June for rice.

There is a recurring, annual hunger season known locally as musim paceklik. As Fox (1977) describes, farmers expect an "ordinary hunger period" of a few months before each harvest. In our data, $30 \%$ of households in the control group report lacking food in the past month in the harvest season survey compared to $43 \%$ in the lean season survey. As we explain below, there is suggestive evidence that farmers face savings and credit constraints that could explain the recurrence of these annual lean seasons.

First, existing storage methods have high depreciation rates. The most prevalent practice of hanging smoked maize from the ceiling leaves it exposed to insects, rodents and moisture, resulting in an annual depreciation rate of approximately $34 \%$ (FAO, 2003). Rice, while less vulnerable than maize, is generally stored in sacks that provide inadequate protection from infestation. Possibly due to transportation costs or a lack of infrastructure, inter-island trade is limited. This could also explain why newer storage technologies have not been introduced locally.

These methods also leave the grain highly visible and subject to what might be termed "social depreciation", which emerges from community pressures to share. ${ }^{14}$

recurring costs that do not amortize over time.

${ }^{11}$ Smallholder subsistence farmers and landless agricultural laborers can both experience consumption seasonality but with possibly different patterns (see, for example, Sen (1981a,b); Khandker and Mahmud (2012)). Landless laborers must deal with variation in labor demand while smallholder subsistence farmers experience food shortages when their food stock depletes before the harvest season.

${ }^{12}$ In the 1983 village census, $73 \%$ of villages in West Timor reported maize as their primary staple while $17 \%$ reported rice.

${ }^{13}$ According to the 2003 village census, in the average village in West Timor, maize is planted on 53\% of village area and rice is planted on $17 \%$.

${ }^{14}$ Consider norms that create pressure on households to share visibly stored assets, as in Baland, Guirkinger, and Mali (2011). 
We collected data on seasonal festival expenditures including amounts spent on own and others' festivities. Festival expenditures are important and constitute $20 \%$ of nonfood expenditures for the control group. On average, 57\% of festival expenditures are incurred on festivities of others.

Furthermore, there are two types of difficulties associated with saving in cash (equivalent to selling staple in the harvest season and buying it back the lean season). First, maize prices are low in the harvest season and high in the lean season. ${ }^{15}$ Second, households are constrained by their remoteness-the average household in our dataset is $25.6 \mathrm{~km}$ from the nearest market. This suggests significant transaction costs associated with converting food to cash and back to food.

Credit, when available, is offered at high rates. Informal annual credit interest rates in West Timor range from $30 \%$ to $50 \%$. Indonesia also has a long association with microfinance. However, Johnston and Morduch (2008) argue that in most cases it remains unsustainable given the small average loan size. Together, these local features point to farmers facing seasonal constraints when borrowing against future harvests for lean season consumption, or when saving in cash or in-kind (due to physical and social depreciation and price fluctuation).

The Indonesian government's efforts on food security are centered around a national rice subsidy program called Raskin. Under this program, basic selection criteria are applied to all households. Eligible households receive a monthly allowance of rice (up to $20 \mathrm{~kg}$ per household) at subsidized prices. In addition to the high fiscal costs, ${ }^{16}$ the program suffers from high leakage (Olken, 2006), possibly due to poor targeting. Finally, as a national program, the timing and provisions under Raskin are not adjusted to seasonal needs in West Timor.

\section{Theoretical Framework}

We use a stylized model to illustrate how local features highlighted in Section 2 can explain the recurrence of annual lean seasons. First, income is seasonal for staple farmers dependent on rain-fed agriculture. Second, consumption patterns are also seasonal in the presence of savings and credit constraints. Households cannot smooth consumption across seasons for two reasons-they cannot borrow against future harvests, and poor storage technologies and seasonal price fluctuations present challenges to saving in-kind and in cash.

We first demonstrate that a "no-seasonality" benchmark has a harvest-to-lean season marginal rate of transformation (MRT) of staples equal to one. In contrast, with savings or credit constraints, seasonal frictions exist (MRT is less than one), which

\footnotetext{
${ }^{15}$ In our surveys, we ask households to predict rice and maize prices for different months in a year. They expect prices to vary significantly for maize but less for rice. The median expected price (per kilogram) for maize in April (harvest) and January (lean) are $2500 \mathrm{Rp}$ and $4000 \mathrm{Rp}$, respectively. For rice, the median expected prices are $6000 \mathrm{Rp}$ for April and $6500 \mathrm{Rp}$ for January. During our study period, the exchange rate was approximately $9000 \mathrm{Rp}$ to 1 USD.

${ }^{16}$ In 2009, the cost of Raskin amounted to $0.23 \%$ of GDP (Trinugroho et al., 2011).
} 
means that lean season consumption is expensive relative to the harvest season. Having described how seasonal frictions give rise to seasonal consumption patterns in Section 3.1, we show in Section 3.2 how food storage and food credit programs address these frictions by introducing new methods to raise the MRT, thereby functioning as a subsidies on lean season consumption.

\subsection{Autarky: Consumption seasonality under savings and credit constraints}

In any year, there is a harvest period $(H)$ and a lean period $(L)$. In each period, utility is a function of staple consumption $(m)$ and consumption of a non-food numeraire good (c). We assume an additively separable utility function: utility in period $t$ is given by $U_{t} \equiv u_{m, t}\left(m_{t}\right)+u_{c, t}\left(c_{t}\right)$, where each $u_{i, t}$ is twice differentiable and strictly concave. For each good $i$ and period $t, u_{i, t}^{\prime}(0)=\infty$ (there are no corner solutions).

Income is seasonal. In any harvest period, the farmer receives an endowment of $e$ units of the staple. ${ }^{17}$ She must allocate the endowment to consumption in both harvest and lean periods. For clarity, since we have an in-kind program, we measure units of consumption in terms of the staple, so that $M_{H}$ represents the amount of endowment allocated to the harvest season and $M_{L}$ represents the amount allocated to the lean season. Within each season, the allocated asset amount is divided across the staple (which has a cash price of $p_{H}$ and $p_{L}$ in harvest and lean, respectively) and non-food (which has a price of 1).

To isolate the mechanisms that generate variation within, rather than across, agricultural cycles, we assume for now that there is no harvest risk. Since endowments are identical in each harvest season, the farmer essentially faces a two-period problem because there is never an incentive to carry resources from one agricultural cycle to the next. For simplicity, we assume there is no discounting across consecutive periods.

The farmer solves the following utility maximization problem:

$$
\begin{array}{cl}
\max _{M_{H} \in[0, e]} & V_{H}\left(M_{H}\right)+V_{L}\left(M_{L}\right) \\
\text { s.t. } & M_{L}=\eta\left(e-M_{H}\right)
\end{array}
$$

Here, the indirect utility functions $V_{H}\left(M_{H}\right)$ and $V_{L}\left(M_{L}\right)$ each represent the maximized utility subject to the budget constraint within a period. In any period $t, V_{t}\left(M_{t}\right)$ is:

$$
\begin{aligned}
\max _{m_{t} \in\left[0, M_{t}\right]} & u_{m, t}\left(m_{t}\right)+u_{c, t}\left(c_{t}\right) \\
\text { s.t. } & c_{t}=p_{t}\left(M_{t}-m_{t}\right)
\end{aligned}
$$

\footnotetext{
${ }^{17}$ This setup can also accommodate labor income in both harvest and lean seasons, which is ignored for simplicity.
} 
The slope of the farmer's inter-seasonal budget constraint (equation (2)) is key to our analysis. Given an allocation in $H$, the resulting asset level in $L$ depends on $\eta$, the marginal rate of transformation (MRT). The inverse of the MRT is the relative cost of lean season consumption-each unit of assets allocated to the lean season requires foregoing $\frac{1}{\eta}$ units in the harvest season.

We model savings and credit constraints as follows. Any staple, $s$, stored in period $H$, becomes $\gamma_{s}$ in period $L$, with $\gamma<1$. The staple is relatively cheaper in the harvest period: $p_{H}<p_{L}$. Finally, borrowing against future harvests incurs a high interest cost of $r>1$ (one unit of borrowed food requires $r$ units of repayment).

Farmers facing savings and credit constraints have difficulty converting endowments in the harvest season to lean season consumption (their MRT is less than one). The MRT depends on the technology the farmer uses to transfer resources across seasons. If the farmer saves in-kind, then in the lean season she has an asset level of $M_{L}=\gamma *\left(e-M_{H}\right)$. Alternatively, if she saves in cash, she earns $p_{H} *\left(e-M_{H}\right)$ from sales, which becomes $M_{L}=\frac{p_{H}}{p_{L}} *\left(e-M_{H}\right)$ units of staple in the lean season. Finally, she could finance her lean season consumption by borrowing and repaying in the following harvest. In this case, $M_{L}=\frac{1}{r}\left(e-M_{H}\right)$. Based on this, the farmer chooses the most effective way to convert resources from the harvest to lean season, so that $\eta=\max \left\{\gamma, \frac{p_{H}}{p_{L}}, \frac{1}{r}\right\}$.

The utility maximization problem yields the following first-order conditions:

$$
u_{m, H}^{\prime}\left(m_{H}\right)=(\eta) u_{m, L}^{\prime}\left(m_{L}\right)=\left(p_{H}\right) u_{c, H}^{\prime}\left(c_{H}\right)=\left(p_{L} \eta\right) u_{c, L}^{\prime}\left(c_{L}\right)
$$

In the absence of frictions, $\eta=1$. This is the "no-seasonality" benchmark. In this case, if utility functions were identical across seasons, consumption too would be identical across seasons. ${ }^{18}$

For our target population in West Timor, seasonal frictions exist (characterized in our model by $\gamma, \frac{p_{H}}{p_{L}}$ and $\frac{1}{r}$ being less than one) so that the MRT is strictly less than one. As a consequence, a unit of lean season staple is more expensive than a unit of harvest season staple. As the first-order conditions show, these frictions cause staple consumption levels to diverge in favor of the harvest season.

We illustrate the consumption-savings problem in Figure 1. Since $V_{H}\left(M_{H}\right)$ and $V_{L}\left(M_{L}\right)$ must be strictly concave, the problem can be described in two dimensions with a budget constraint and well-behaved indifference curves. The horizontal and vertical axis depict asset allocations (in staple units) to the harvest and lean seasons, respectively. The horizontal intercept depicts the staple endowment, $e$. Without seasonal frictions, the slope of the budget constraint is -1 . If preferences were identical across seasons, the utility-maximizing bundle for the "no-seasonality" benchmark would be at the intersection of the budget constraint and the 45-degree line, $M^{0}$.

\footnotetext{
${ }^{18}$ This framework also accommodates the possibility that preferences and consumption needs vary across the agricultural cycle, as in Behrman, Foster, and Rosenzweig (1997). For expositional simplicity, we do not separately model the cases of consumption for inferior and Giffen foods, as in Jensen and Miller (2008).
} 
With seasonal frictions, the budget constraint is flatter because the MRT is less than one. The agent's utility maximizing bundle will involve a transfer of assets from harvest to lean seasons, to a point such as $M^{*}$. As the first-order conditions (equation 5) show, if utility functions are identical across seasons, seasonal frictions result in more staples being consumed in the harvest season than in the lean season. As we show below, storage and credit programs that reduce seasonal frictions can raise the MRT, thereby subsidizing lean season consumption.

\subsection{Storage and Credit Programs}

We model the storage program as a technological innovation that raises $\gamma$ to some $\bar{\gamma}$. As shown in Figure 1, for households that initially faced an MRT of $\eta<\bar{\gamma}$, the posttreatment budget constraint pivots upwards. For the same endowment, $e$, this translates into an expanded budget set. This is akin to the effect of improved interest rates on savings. The extent of the expansion of the budget set depends on the difference between $\bar{\gamma}$ and the baseline MRT. Conditional on $\bar{\gamma}$, we expect benefits to be weakly larger for households with lower baseline $\gamma$ (under the assumption that $r$ and $\frac{p_{H}}{p_{L}}$ are uncorrelated with the household's $\gamma$ ).

With credit, the agent has the option to borrow some maize, $b$, in period $L$, which is repaid in period $H$ with interest, as $\bar{r} b$, where $\bar{r}>1$. If, as we assume, $\bar{r}$ is sufficiently low (so that $\frac{1}{\bar{r}}>\eta$ ), the farmer will choose to fund lean season consumption by borrowing against the next harvest rather than saving from the previous one. The credit program therefore improves the MRT between harvest and lean season consumptions, but with a change in timing. In autarky, one unit of lean season staple would require $\frac{1}{\eta}$ units of savings in the preceding harvest. Under credit, one unit of lean season staple requires $\bar{r}$ units of repayment in the succeeding harvest. ${ }^{19}$

While storage and credit programs differ in their implementation (as we explain in Section 4), in the abstract, both programs can be interpreted as technological innovations that help farmers more effectively convert staple output in the harvest season to lean season consumption. By raising the MRT, both programs lower the cost of lean season consumption $\left(\frac{1}{\eta}\right)$.

Treatment effects can be analyzed within this framework of lean season subsidies. First, there are across-season effects. The post-treatment consumption bundles under credit and storage ( $\bar{M}$ and $\bar{M}^{\prime}$ in Figure 1 depict two possibilities) depend on the relative magnitudes of income and substitution effects. The substitution effect should increase lean season consumption (because $M_{L}$ is relatively cheaper) and decrease harvest season consumption $\left(M_{H}\right)$. If, as we assume, both goods are normal, then income effects (through the expanded budget set) should increase both $M_{L}$ and $M_{H}$. We expect total lean season consumption to be weakly higher $\left(\bar{M}\right.$ and $\bar{M}^{\prime}$ should be north of $M^{*}$ in Fig-

\footnotetext{
${ }^{19}$ Our credit programs charged low interest rates so that $\bar{r}$ is plausibly low enough for credit to be an improvement over autarky $\left(\frac{1}{\bar{r}}>\eta\right)$. The agent might wish to borrow not just for consumption but for purposes of arbitrage (to sell in the lean season and buy back in the harvest season). We assume, as explained in Section 4, that there are institutional limits to loan sizes that prevent this.
} 
ure 1) as a result of both income and substitution effects whereas total harvest season consumption $\left(M_{H}\right)$ may rise or fall since income and substitution effects oppose each other. If substitution effects dominate, we expect a move to a point such as $\bar{M}$ (west of $M^{*}$ ); if income effects dominate, we expect a move to a point such as $\bar{M}^{\prime}$ (east of $M^{*}$ ).

Second, the new levels of $M_{H}$ and $M_{L}$ result in new allocations of food and nonfood consumption within each season. These are captured by pure income effects as depicted in Figure 2. For example, if there is a rise in $M_{t}$ in any period $t$, it can be represented as an outward parallel shift of the within-period budget constraint. The consumption bundle then moves from $\left(m_{t}^{*}, c_{t}^{*}\right)$ to the new budget line.

How a change in $M_{t}$ is allocated across $m_{t}$ and $c_{t}$ depends on rates of change of marginal utilities $\left(u_{m, t}^{\prime}, u_{c, t}^{\prime}\right)$. Under homothetic utility, we expect a rise in both forms of consumption, to a point such as $\left(\bar{m}_{t}, \bar{c}_{t}\right)$. On the other hand, if individuals are close to food satiation, most changes will be captured by non-food consumption. A quasilinear utility function helps demonstrate this point: the first tranches of income are allocated to food, but additional income gains are directed towards non-food consumption so that the agent arrives at a point such as $\left(\bar{m}_{t}^{\prime}, \bar{c}_{t}^{\prime}\right)$.

To summarize, the programs are designed to raise the harvest-to-lean MRT, $\eta$. By raising the returns to the staple farmer's asset which is either consumed directly or converted into other consumption, they subsidize both food and non-food in the lean season. The overall impacts of these subsidies depend on income effects (which raise all consumption) and substitution effects (which raise lean season consumption and lower harvest season consumption).

\subsection{Risk}

Risk can matter differently for credit and storage. We argue that credit is better than storage at dampening the fluctuations associated with risky outcomes. This happens through the programs' interaction with both harvest risk and storage risk.

First, the benefits of storage depend on the realized harvest. Under harvest failure, if there is nothing to store, there is nothing to be gained from improved storage. Credit, on the other hand, provides implicit insurance through limited liability (as described in Section 4). When households experience low harvests from verifiable shocks, they are permitted to defer their debt until the following harvest.

Second, under storage, households face a risk even after harvest since the technologies are not foolproof. For example, under certain conditions, stored maize could be damaged by aflatoxins. While the storage treatment is expected to raise the MRT, the actual rise in MRT is uncertain. This can limit the ability of households to precisely close seasonal gaps through storage. Under credit, this risk is absorbed by the program since the interest rate is fixed and is independent of storage risk. In effect, credit offers households a fixed MRT while storage does not. Therefore, when comparing consumption between any two consecutive harvest and lean seasons, we expect seasonal gaps to be lower under credit than under storage. In the remaining sections, we refer to this as a "seasonal smoothing" effect. 


\section{Program Design}

Given global concerns about food policy, we were approached by the World Bank in Jakarta to design and evaluate innovative food security solutions. While both programs have features that are tailored to West Timor, they share similarities with other food programs. See Gelay (2008), Lines (2011) and Zeller (2001) for examples of food storage programs and Khandker and Mahmud (2012) and Mohan et al. (2007) for examples of credit programs for consumption purposes.

The implementation and evaluation of the programs were funded by the Japanese Social Development Fund. The treatments were implemented in September 2008 and lasted 3 years. The programs were implemented by two local NGOs, Yayasan Alfa Omega (YAO) and Yayasan Tanaoba Lais Manekat (TLM), each of which operated independently in two districts. Both NGOs were selected because they had experience implementing cash-based savings and microcredit programs in West Timor. Participants were informed that the food storage and food credit programs were part of a three-year pilot, sponsored by the World Bank. Both programs were introduced as new programs, with no ties to other programs sponsored by the NGOs. All facilitators on the field were newly hired and trained.

The project covered 96 rural villages across all 4 districts, or kabupatens, in West Timor. These villages were selected by the NGOs, who were instructed to choose villages that were far enough from each other to avoid contamination effects.

Treatment assignment was conducted by us and stratified by district. Within each district, 24 villages were randomly assigned in equal proportions to the control group (no treatment), or one of three treatment groups (pure storage, contract storage, and credit, to be discussed below). To be eligible for storage or credit programs, the NGOs required participants to be married (or once-married) female farmers.

\subsection{Storage}

The storage treatments were designed to subsidize lean season consumption by loosening the savings constraint which, as described in Section 2, can come from physical depreciation, social depreciation, and price variation. Individuals were offered storage materials for free. We implemented two storage treatments: pure storage and commitment storage.

Based on our budget and power calculations, storage groups of up to 108 women per village were formed through public announcements in the lean season. In total, there were 2,433 members under Alfa Omega and 2,529 members under TLM. While grain was stored individually, training was provided at the group level. Participants were provided with a choice of high capacity drums (180 kg, at a cost of Rp 250,000), lower capacity jerrycans (40 kg, at a cost of Rp 47,000), and sacks. They were trained in the required drying methods and provided with warnings about aflatoxins which can destroy large quantities if the grain is exposed to moisture. Drums were the most popular method of storage, and more than $80 \%$ of stored staples were maize. 
Superior storage not only improve rates of return, it might also reduce household vulnerability to self-control problems and social pressures. ${ }^{20}$ To target this problem further, we assigned a quarter of our villages to a commitment storage treatment. The commitment storage treatment used the same storage technologies as pure storage. However, individuals were required to sign a contract under which they agreed to a restriction on withdrawals until a self-specified date. The contract allowed for early withdrawals only in the case of explicitly defined and verifiable emergencies. Storage equipment was then sealed. The implementing NGOs were tasked with carrying out random audits to check the seal. If the seal was broken before the contracted date, and if the individual did not have a verifiable emergency, she would be denied future access to the program. If the pure storage treatment is equivalent to a savings account with a high interest rate, the contract storage treatment is equivalent to a term fixed deposit during which savings are made illiquid.

Unfortunately, we found that the distinctions between pure and contract storage were not strictly adhered to during implementation. In particular, participants in pure storage too were required to maintain written records specifying anticipated withdrawal dates. While these were not contractually binding, they served to discourage them from making intermediate withdrawals as the pure storage program was initially designed to allow. For these reasons, we do not distinguish between the pure storage and contract storage treatments in our analysis. ${ }^{21}$

Given the simplicity of our technological innovation, it is somewhat surprising that it was not already in use. Part of this can be explained by the difficulty of securing storage equipment. Small-scale storage materials are not readily available in local markets. Large storage warehouses in urban areas use oil drums. These are unsuitable for use at the household level due to transportation difficulties and residual oil. Basic sacks, while providing protection from moisture, do not provide necessary barriers against rodents. For the first year, we imported storage products from another island. Materials arrived too late to be used in the harvest season of year one. This meant that storage treatments in most areas started in the harvest season of year two. For the second year, our agricultural specialists managed to locally source sufficiently secure storage materials.

The cost of the program consists of two main components. The first is procurement costs used to purchase storage equipment. Procurement costs are one-time, upfront costs. The average procurement cost per storage participant was $326,366 \mathrm{Rp}^{22}$ The second component consists of implementation costs (mostly wages for facilitators but also management fees for the NGOs, and indirect costs including rent for offices in the field). This component is a recurring cost. To divide these costs between storage and credit, we assume that one third of staff and facilitator time was spent on credit while

\footnotetext{
${ }^{20}$ See Ashraf, Karlan, and Yin (2006) for a motivation.

${ }^{21}$ We repeated the empirical analysis treating pure and contract villages separately. There were no differences between the two treatment groups.

${ }^{22}$ Calculated as $(714,031,000 \mathrm{Rp}+905,395,500 \mathrm{Rp}) /(2433$ members +2529 members $)$, where the numerators include the total procurement costs for Alfa Omega villages and TLM villages, respectively.
} 
two-thirds was spent on storage (the typical facilitator was assigned to three villages - two storage villages and one credit village). The annual implementation cost for storage was $254,803 \mathrm{Rp}$ per household. ${ }^{23}$

\subsection{Credit}

As the storage program aimed to subsidize lean season consumption by loosening the savings constraint, the food credit program did the same by loosening the credit constraint. It was designed as a staple-based microcredit program, with repayment schedules that target local seasonal patterns. The program was similar to the cash-based women's microcredit program created under the Kecamatan Development Project (see Olken (2007) for more details), except that we offered staple food rather than cash loans and focused on financing lean season staple consumption instead of income-generating activities.

In September 2008, the NGOs introduced the program at churches and through local leaders' networks. As with storage, credit groups of up to 108 eligible women were formed in each treated village. Groups then elected their internal leaders and administrators. In total, there were 1229 and 1374 credit participants in Alfa Omega and TLM villages, respectively.

Disbursement and repayment were timed to match local seasonal patterns. In the middle of each lean season (typically between December and January), participants filled out forms to request the amount and type of staple they wished to borrow. The loans were to be repaid in kind, with interest, after the following harvest (typically between April and June). The credit groups held meetings to determine a common date for the disbursement of food. The repayment date was determined by the anticipated timing of the participant's harvest. In practice, most loan terms were approximately 6 months.

The seed capital for the credit program was gifted to the groups. This was used to facilitate grain procurement and storage equipment. Group members voted to borrow either rice or maize. Grain to be used for credit was then sourced from nearby districts by the NGOs and the group leaders. In our data, $45 \%$ of all loans issued were rice and $55 \%$ were maize.

Facilitators collected data on plot size and previous harvests to determine loan capacity, which ranged from $50 \mathrm{~kg}$ to $200 \mathrm{~kg}$ per member. This externally imposed loan ceiling ensured that participants could not borrow unlimited amounts for the purposes of arbitrage. For maize, the mean loan was $85 \mathrm{~kg}$ and the median was $50 \mathrm{~kg}$. For rice, the mean loan was $95 \mathrm{~kg}$ and the median was $100 \mathrm{~kg}$.

Loans accumulated simple interest at the rate of $1.5 \%$ per month (measured by

\footnotetext{
${ }^{23}$ The total implementation costs over three years were 3,072,618,032 Rp for Alfa Omega and 2,616,875,216 Rp for TLM (the annual implementation costs are calculated by dividing by 3 years). The annual implementation cost for storage was calculated as $\left(\frac{2}{3}\right) *\left(\frac{1}{3 \text { years }}\right) *(3,072,618,032+$ $2,616,875,216) /(2,433+2,529)$. If we include both one-time procurement costs and annual implementation costs, the average cost per storage participant would be 581,169 Rp.
} 
weight) with a loan fee of $1.5 \%$. In general, households paid an accumulated $10.5 \%$ interest in the harvest season. ${ }^{24}$ This suggests an improved MRT, given existing estimates of retention rates under traditional storage (around 66\%, as discussed in Section 2). While training and monthly meetings happened at the group level, lending and liability were individual. The punishment for default was permanent expulsion from the groups. Exceptions were made for natural catastrophes and harvest failures. In these cases, households were permitted to roll over debt to the following agricultural cycle.

Repaid grain was stored in drums and sacks until the next round of disbursement. While the program grant was used as seed money to provide the first round of loans, repaid food was expected to sustain future loans. Since the credit program also took advantage of superior storage technologies, relatively low interest rates were sustainable. Furthermore, the credit contract provided implicit insurance in two ways. First, by allowing households to roll over debt, it protected borrowers from harvest risk. Second, by lending at a fixed interest rate, it protected borrowers from the storage risk they would face if storing on their own, as discussed in Section 3.3.

Repayment rates were $100 \%$ except in instances of harvest failure, when debt was deferred to the following harvest. In the first and third years, TLM villages faced major harvest failures (repayment rates in these harvest periods were initially $60 \%$ and $4 \%$ ). In the second year, some Alfa Omega villages faced harvest failures (repayment rates were initially $80 \%$ ). For harvest failures in the first two years, full repayment was received within one year of default. We do not have data on repayment following harvest failures in the third year as the formal program had ended by that time. The high repayment rates strongly suggest that such a program can be self-sustaining.

For credit, the average procurement cost per credit participant was $727,488 \mathrm{Rp}^{25}$ This was used to purchase and transport the first loan disbursements to the credit villages. For credit, the annual implementation cost per participant was $242,861 \mathrm{Rp}^{26}$

\section{Data}

Enumerators visited 2,877 agricultural households twice each year for three years, once during the lean season and once during the harvest season. We had two main surveys, a household survey (the main survey) and an individual survey (to collect demographic information about household members). The surveys were administered by the agricultural institute of a local university, Lembaga Penelitian Undana. We had to drop 7 households because we could not merge information from the two sets of surveys (their household identifiers were not the same across the household and individual surveys).

\footnotetext{
${ }^{24}$ The terms were based on standard contracts under SPP (the women's microcredit program under KDP) and other microcredit programs (including those offered by TLM and YAO).

${ }^{25}$ Calculated as $(1,408,868,000 \mathrm{Rp}+484,784,000 \mathrm{Rp}) /(1229$ members +1374 members $)$, where the numerators are the procurement costs for Alfa Omega villages and TLM villages respectively.

${ }^{26}$ This was calculated as, $\left(\frac{1}{3}\right) *\left(\frac{1}{3 \text { years }}\right) *(3,072,618,032+2,616,875,216) /(1,229+1,374)$. If we include both one-time procurement costs and annual implementation costs, the average cost per credit participant was 970,349 Rp.
} 
There was no attrition. Therefore, our final sample comprises 2,870 households (713 from control villages, 720 from credit villages and 1,437 from storage villages) and 17,220 observations (at the household-season level).

Figure 3 describes the timing of the surveys in relation to harvest seasons (April to June, in italics) and lean seasons (November to February, in bold). There were six survey rounds. Odd-numbered rounds (1,3 and 5) correspond to lean season surveys and even-numbered rounds correspond to harvest season surveys. Column 1 shows that the first round was conducted between September and November 2008, just before the start of the lean season. Because many of the villages were extremely remote, each survey round took two to three months to complete. Due to budget delays, the first two harvest season surveys (rounds 2 and 4) were delayed by 3 months and began in July.

The following columns in Figure 3 show how the timing of the surveys coincided with the treatments. For credit, food disbursements occurred between the months of December and January (the peak of the lean season) and repayments were around harvest months (April to June). Comparing columns 1 and 2, we can see that credit has five rounds of surveys post treatment (rounds 2 to 6 ) and one pre-treatment round that was conducted in the lean season. For credit, we do not have a pre-treatment harvest season survey.

For storage, the final column shows that equipment only arrived between July and August of 2009 (coinciding with round 2, in column 1). Since this was already several months after the first harvest, little was stored until the subsequent harvest season (round 4). Therefore, we define rounds 4 to 6 as post treatment rounds for storage. We have one pre-treatment harvest survey and two pre-treatment lean surveys.

Column 1 of Table 1 reports the baseline means of the control group. The average age of the household head is 44.8 years. $78 \%$ of household heads have completed primary school and $24.1 \%$ have completed lower secondary school ( 9 years of schooling). Only $6.7 \%$ report having savings in a bank account. The average household has 4.832 members. Staples are an important food item. The average individual consumes 40.88 kilocalories from rice and maize per month (or 1.36 kilocalories per capita per day). This is about $65 \%$ of the minimum recommended daily energy level commonly used in poverty statistics (2.1 kilocalories) and $70 \%$ of the average calorie intake per capita per day (1.96 kilocalories) in rural Indonesia in 2010 (BPS, 2013). Other studies have also found that about $60 \%$ to $70 \%$ of calories in the typical poor person's diet comes from the primary staple in the region (see, for example, Jensen and Miller (2011)).

\section{Describing key outcomes}

We have four categories of outcomes, which we report in four panels in all tables. We explain how these variables are constructed in Table A1 in the Appendix. The first category (Panel A in the tables) includes common measures of overall well-being, including $\log$ (Staple consumed, $k C$ al),${ }^{27} \log$ (Non-food expenditure), $\log$ (Reported income). All these are reported as per capita monthly measures. Reported income is the

\footnotetext{
${ }^{27}$ Staple consumption is calculated as rice consumed plus maize consumed (both in calories), as these are the two main staples.
} 
amount households report as their income (from harvest sales, wages, remittances and gifts) in the past month. Since we are taking logs, we miss some observations that are zeros. The appendix includes details on the construction of key outcomes and related data issues.

The second category includes measures of seasonal differences in consumption and income (Panel B). For each agricultural cycle, we calculate the absolute difference between the harvest and lean season levels of staple consumption, non-food expenditure and income. ${ }^{28}$ For example, the seasonal gap in $\log$ (Staple consumed) is measured as the absolute difference between rounds 2 and 3 and the absolute difference between rounds 4 and 5. We discuss why we use absolute differences instead of pure differences in the appendix, where we also report results using pure differences.

The third category includes indicator variables meant to capture food shortages (Panel C). This outcome is of independent interest because food security is commonly defined as having access to adequate food at any time (Khandker and Mahmud, 2012). By asking households to report whether they think they have or expect to have adequate food, these indicators capture the extensive margin of food shortages, while calories consumed (reported in Panel A) capture the intensive margin. ${ }^{29}$ We have four outcomes in Panel C. The first three measure whether households expect to have adequate food in the following January, the following November (both lean seasons) and the following April (harvest season). The fourth is an indicator of whether households faced a food shortage in the past month. To summarize, Panel $\mathrm{C}$ measures anticipated food access for future months and reported food access in the past month.

The final category includes self-reported measures related to health (Panel D). We have three variables-an indicator variable of whether the household was unable to afford health expenditures in the past month, the number of household members who reported any sickness in the past three months, and the total number of sick days reported (totaled over all members who reported they were sick in the past three months). The last two health outcomes are scaled in per capita per month units so that we do not have the mechanical effect of larger household sizes leading to more reported sick days and more reported sick persons.

We use these four categories to measure whether our treatments improved wellbeing. Improvements in consumption and income (Panel A) and health (Panel D) and reductions in food shortages (Panel C) are associated with improvements in well-being. Reductions in seasonal gaps (Panel B) can be interpreted as a welfare improvement, under the assumption of identical, separable, and concave utility functions for both seasons (more details are in the appendix). Panels A, C and D are common in the literature on food policies and the Panel B is specific to seasonality.

A limitation of our data is that we only collected food intake information for a few food items. We have consumption measures for primary staples (rice and maize, which typically represent $60 \%$ to $70 \%$ of household calories) and other major food items

\footnotetext{
${ }^{28}$ For seasonal differences, we use differences in the monthly non-food expenditure items only.

${ }^{29}$ These measures also account for the possibility that household calorie needs vary in unobserved ways (Jensen and Miller, 2010), so that "adequate" is a subjective notion.
} 
(cassava, fruits and beans). For budgetary reasons, we did not collect data on other foods such as meat and seafood. As a result, we are unable to build a truly comprehensive measure of food consumption. If households substituted towards consuming non-staples not measured by us, our analysis will miss this margin of adjustment.

\section{Multiple outcomes and mean effects analysis}

To address concerns associated with having many outcomes, we follow Kling, Liebman, and Katz (2007) and use mean effects analysis. We group outcomes into the four categories above and then construct a summary index for each category. For each category with $Y_{1}, \ldots, Y_{K}$ outcomes, we calculate the standardized outcomes, $y_{1}, \ldots, y_{K}$, as the outcome, $Y_{k}$, minus its baseline mean in the control group, divided by the baseline standard deviation in the control group. ${ }^{30}$ Finally, we create the summary index by averaging over all $K$ standardized outcomes. The Consumption and Income Index and the Heatlh Index are defined so that an increase in the index is desirable. The Food Shortage Index and Seasonal Gap Index are defined so that a reduction is desirable.

Using a summary index avoids the over-testing problem because each index is one regression and the probability of false rejection does not increase as we add outcomes to the index. The downside is that it is hard to interpret the indices. If we find that an index increased, we would like to know which components are significant in isolation. Therefore, in each table, we report results on both the summary index for each category of outcomes and the individual coefficients. Mean effects analysis is widely used by other randomized control trials. ${ }^{31}$ Given the large number of outcomes, we focus on reporting results that are significant at the $1 \%$ or $5 \%$ levels only.

\section{Balance checks}

Table 1 reports results from tests of whether treatment and control villages are balanced, using the first survey round. Columns 2 to 5 report results from OLS regressions comparing storage to control villages, controlling for district fixed effects and clustering standard errors at the village level. We report p-values for tests of the coefficient on the treatment indicator being zero. Columns 6 to 8 report results for credit versus control villages. The full estimation samples include 2,150 households for storage and 1,433 households for credit. The outcomes are organized into six panels: Panels A

\footnotetext{
${ }^{30}$ It is more common to standardize using the contemporaneous means and standard deviations for the control group. However, we chose to use the baseline control group mean and standard deviation because of the mis-assignment problem discussed in the next section (three villages assigned as controls were treated).

${ }^{31}$ An alternative approach is to make Bonferroni adjustments. The basic Bonferroni adjustment calculates upper bounds for family-wise error rates by multiplying the per comparison p-value by the number of estimates within a family of hypotheses. This bound is the exact family-wise p-value when the outcomes in the family are independent of each other. Intuitively, the Bonferroni adjustments have lower statistical power when the outcomes are highly correlated, as in our case. For example, in Panel C, anticipation of food shortages in January, April and November are likely to be highly correlated so that Bonferroni would result in adjusted p-values that are too high. In other words, the upper bound is less informative because we would fail to reject too often. See Kling and Liebman (2004) for more details.
} 
to $\mathrm{D}$ correspond to the outcomes reported in the remaining tables, Panel $\mathrm{E}$ examines agricultural production and storage behavior and Panel F reports baseline household characteristics.

For storage, one outcome out of 25 tests has a p-value at or below 5\%. In Panel $\mathrm{F}$, Number of motorcycles owned has a mean difference of 0.051 and a $\mathrm{p}$-value of $0.8 \%$ (compared to the control group mean of 0.067). However, a difference of 0.051 motorcycles seems small and economically insignificant. For credit, one out of 25 tests has a p-value at or below 5\% (1(Anticipate food shortage in November) in Panel C has a p-value of $4.7 \%$ ). This baseline difference is the opposite of those in our results, so it biases us against our findings. Importantly, all our results are robust to controlling for baseline values for the dependent variable and controlling for baseline differences in household characteristics reported in Panel F in Table 1 (including the Number of motorcycles owned).

\section{Estimation}

Our main specification is an instrumental variable regression that compares treatment and control villages, and pools all post treatment survey rounds.

$$
y_{i v d}=\alpha+\beta_{1} T A K E U P_{i v d}+\theta_{d}+\varepsilon_{i v d}
$$

where $y_{i v d}$ is the outcome for household $i$, in village $v$ in district $d$. We use the treatment assignments $\left(T R E A T_{v d}\right)$ to instrument for a dummy that is 1 if household $i$ participated in the programs $\left(T A K E U P_{i v d}\right)$. The take-up rate for credit was $40 \%$ and the take-up rate for storage was $42 \%$. All specifications control for district fixed effects, $\theta_{d}$, since treatment was assigned randomly across villages within each district. We estimate the regressions separately for credit and for storage. Standard errors are clustered at the village level.

The key parameter of interest is $\beta_{1}$. An improvement in well-being would be associated with increases in consumption and income levels and improvements in health $\left(\beta_{1}>0\right.$ in Panels A and D) and decreases in seasonal differences and food shortages $\left(\beta_{1}<0\right.$ for Panels $\mathrm{B}$ and $\left.\mathrm{C}\right)$.

As discussed in the theory, both seasonal food programs were designed to subsidize lean season consumption by raising the harvest-to-lean MRT of staples. By doing so, the treatments can generate income and substitution effects. While we do not estimate these effects separately, under some assumptions, we can detect which effects are dominant by observing the signs of the overall effects on consumption in each season. For normal goods, both substitution and income effects increase lean season consumption $\left(\beta_{1}>0\right)$ while substitution and income effects have opposing effects on harvest season consumption $\left(\beta_{1}>0\right.$ if the income effect dominates or $\beta_{1}<0$ if the substitution effect dominates). Therefore, the sign of the overall effect on harvest season outcomes indicates which effect is dominant. ${ }^{32}$ If harvest consumption increases, income effects are

\footnotetext{
${ }^{32}$ For inferior goods, income and substitution effects are opposite-signed for lean season consumption.
} 
dominant, pointing to budget set expansions and unambiguous welfare improvements. However, decreases in harvest season consumption have ambiguous welfare implications. They are consistent with dominant substitution effects but also with budget set contractions.

Unfortunately, due to a mis-communication, TLM assigned the wrong treatment for nine villages. To address this, we report our main results using only the intended assignment. We also report estimates for each NGO separately in the appendix (Tables A5 and A6). These estimates by NGO remain internally valid since each NGO managed two districts and random assignment was stratified by district. We believe the mis-assignment error is orthogonal to unobserved village characteristics. The assignment was performed by the authors who were based in the United States at the time of assignment. The treatment assignment was sent via email but one NGO mistakenly used the treatment assignment from an older email. When we estimate treatment effects by NGO, the results tend to be more significant for Alfa Omega villages than for TLM villages. This suggests our results are not driven by mis-assignment as there was no mis-assignment in Alfa Omega villages.

\section{Results}

We present our main results in Section 7.1, discuss robustness checks in 7.2, describe mechanisms in 7.3, and provide cost benefit calculations in 7.4.

\subsection{Main results}

Columns 1-3 of Table 2 report IV estimates for the storage treatment compared to the control group. Each pair of cells in this table reports an IV estimate of $\beta_{1}$ in equation 6 and its standard error. We report results using all post treatment seasons (column 1), lean seasons only (column 2) and harvest seasons only (column 3). Similarly, we report results for credit compared to the control group in columns 5 to 7 . Columns 4 and 8, labeled N(All), report sample sizes for IV regressions using all seasons. We first discuss the impacts of storage and credit on consumption and reported income (Panel A). This is our main result. We then discuss effects on seasonal differences in consumption and income (Panel B), effects on food shortages (Panel C) and on health (Panel D).

The main result is an increase in the Consumption and Income Index by 0.246 units for storage (Panel A, column 1) and by 0.267 units in the harvest season for credit (column 7). For storage, the treatment effects are similar for both lean (0.188) and harvest seasons (0.277). ${ }^{33}$ As discussed in Section 6, these increases, particularly in

Substitution effects are always positive for lean season consumption and negative for harvest season consumption. But income effects depend on whether goods are normal or inferior.

${ }^{33}$ The harvest season effect is significant at the $5 \%$ level, but the lean season effect is not statistically significant. This is probably because, for storage, we have two post-treatment harvest season surveys 
the harvest season, are consistent with dominant income effects coming from budget set expansions.

For storage, the increase in the Consumption and Income Index is driven by a $31.1 \%$ and a $33.2 \%$ increase in non-food expenditure in the lean and harvest seasons, respectively. ${ }^{34}$ The most responsive expenditure margins are personal consumption goods. For credit, the increase in the Consumption and Income Index is driven by increases in reported income (66.2\% in the harvest season). ${ }^{35}$ As we do not observe decreases in consumption, the higher reported income is consistent with increases in the consumption of other goods not measured by us (this could include other food items, such as meat and seafood, or other non-food items).

We estimate precise zero effects on staple food consumption. The effect on calories consumed from staples is $1.4 \%$ (for storage) and $6 \%$ (for credit). When we repeat the regression in levels scaled to per capita per day units, we estimate a decrease of 4.484 calories per capita per day (for storage) and an increase of 124.4 calories (for credit). This is not due to a lack of variation in calories consumed. The control group has a baseline mean of 1360 calories per capita per day and a standard deviation of 853 calories (Table 1).

Given that the policy reduced the relative cost of lean season consumption, substitution effects should increase staple consumption in the lean season. However, we do not detect this increase. Moreover, transaction costs (which are likely to be significant for rural households) should bias us towards finding effects on staple consumption (relative to other goods), since our programs focus on staples, instead of vouchers or cash. This makes the null effects on staples more striking. We cannot rule out increases in other food items, including some sources of protein, due to data limitations. However, we did collect data on a few other food items (fruits, beans and cassava) and did not detect any changes on their consumption patterns.

As shown in Figure 2, the null treatment effects along the staple food margin are consistent with the marginal utility of staples diminishing more rapidly than marginal utilities of other forms of consumption. In our model, the generalized utility function is agnostic on this, but more specific functional form assumptions (such as quasilinear utility, a reasonable conjecture in this setting) could explain this pattern. These results suggest the average household could be close to staple food satiation. This would be consistent with the types of food preferences observed in Banerjee and Duflo (2007)

(rounds 4 and 6) but only one for the lean season (round 5).

${ }^{34}$ This increase is large compared to the value of the storage equipment households received for free. Most households in the storage treatment received storage equipment valued between 47,000 Rp and $250,000 \mathrm{Rp}$. In each of the three post treatment survey rounds for storage, total non-food expenditure (per month per household) increased by 55,000 Rp, 76,000 Rp and 76,000 Rp, respectively. The overall cost-effectiveness, of course, depends on how we annualize these effects on monthly expenditures. We discuss this in Section 7.4.

${ }^{35}$ The effect on reported income is mostly driven by increases in income from sales of harvest output rather than wages, remittances or gifts. This is consistent with the model. Credit offers a cheaper way to fund lean season consumption. If the household chooses not to raise lean season consumption (as in this case), it is now able to sell more of its harvest output to fund other forms of consumption. 
and Jensen and Miller (2008). Now that we have discussed level effects, we turn to seasonal differences.

Panel B shows that credit has seasonal smoothing effects but storage does not. For storage, the effects on the Seasonal Gap Index are relatively precise zero effects (the $95 \%$ confidence interval ranges from -0.178 to 0.124 standardized units). For credit, the effect on the Seasonal Gap Index is statistically insignificant, but the absolute seasonal gap in the log of monthly non-food expenditure items declines by 0.16 units. $^{36}$ The mean seasonal gap in monthly non-food expenditure items for the control group in the baseline is $10,406 \mathrm{Rp}$. When we estimate treatment effects by survey rounds, we find that most of the decline occurs in the first cycle (|round 2-round 3|) and appears to be driven by decreases in harvest season consumption (round 2) and increases in lean season consumption (round 3). This is consistent with our discussion in Section 3.3 that explains features of the credit program that insure participants against harvest risk and storage risk, which could explain why credit appears to have stronger seasonal smoothing effects than storage. Turning to the Food Shortage Index in Panel C, we see that the effects are largely negative, but statistically insignificant.

Finally, Panel D reports health effects. For storage, the health effects are close to zero with relatively narrow confidence intervals (the $95 \%$ confidence interval ranges from -0.146 to 0.145 standardized units, Panel D, column 1). For credit, we find insignificant effects on health when we pool both seasons. Reported health is better in the lean season (the Health Index is 0.188 higher though this is not significant) but is worse in the harvest season (the Health Index is lower by 0.330 units). This is driven by a $10.5 \%$ higher likelihood of households reporting a difficulty to meet health expenditure payments, 0.185 more sick days per capita per month and a $0.6 \%$ higher likelihood that a household member reported any sickness in a month. While the deterioration in health in the harvest season is a concern, it is reassuring that the magnitudes are not large and that the overall health effects (using all seasons) are insignificant.

In summary, both storage and credit led to sizeable increases in the Consumption and Income Index, driven by increases in non-food expenditure and reported income but with zero effects on staple consumption. Credit had some seasonal smoothing effects (driven by smaller seasonal differences in monthly non-food expenditure items). But there was also moderately worse reported health in the harvest season, with no effects on overall health when we pool both seasons. Storage had zero seasonal smoothing and health effects. The effects on food shortages are inconclusive because the standard errors are too large.

\subsection{Robustness checks}

Table 3 reports robustness checks. Column 1 reports the main IV results of Table 2. Column 2 controls for the value of the dependent variable in the baseline. Column

\footnotetext{
${ }^{36}$ When calculating seasonal differences, we only include differences in monthly non-food expenditure items (rent, utilities, health bills and personal consumption items).
} 
3 adds baseline values for all household characteristics reported in Panel F of Table 1. These two specifications are included because we might be concerned that predetermined differences shown in the balance checks reported in Table 1 are driving the treatment effect estimates. Column 4 reports OLS estimates. Columns 5 to 8 report similar robustness checks for credit. ${ }^{37}$ For all specifications, we only report results that pool all seasons (instead of one table for each specification). The results for lean and harvest season surveys are broadly similar.

For both treatments, the results are robust across all specifications. The estimates for staple consumption remain close to zero and the consumption effects remain large for storage. For credit, the effect on income remains high for the harvest season (not reported). The OLS estimates are about half of the IV estimates (in line with take up rates that are around $40 \%$ for both treatments). Importantly, the results are robust to controlling for baseline differences (columns 2, 3, 6 and 7), suggesting the baseline differences reported in Table 1 are most likely due to sampling error, and that treatment versus control differences in post treatment outcomes are not caused by observed baseline differences.

\subsection{Mechanisms}

Other budget set effects

The main mechanism by which both programs expand budget sets is through the raising of the harvest-to-lean MRT. In the theory, the budget constraint (equation 2) included only agricultural endowments and assumed away other sources of revenue that could give rise to income effects, including wages and private transfers (gifts and remittances). We explore these potential mechanisms in Table 4.

We see that neither program affected other budget set factors, providing further support that the income effects above are directly due to the programs' effect on MRT. One concern is that the null staple effects might arise because our transfers are exactly offset or crowded out by other transfers. If this is true, then we should see decreases in the receipt of private transfers (gifts and remittances). Table 4 shows that the treatments did not affect these transfers (columns 1 and 2) nor did it affect wage income (column $3)$. Another concern is that staple consumption might have increased at the household level but not at the per capita level if household size increased. Column 4 shows that this is not the case.

\section{Evidence of savings constraints loosening under storage}

Further analysis suggests that the main mechanism behind the effects of storage on consumption is an alleviation of the savings constraint, as discussed in the model. We

\footnotetext{
${ }^{37} \mathrm{We}$ also tried estimating specifications with household fixed effects and testing for differences between treatment and control groups but the standard errors were large. Since treatment was randomly assigned at the village level, the household fixed effect specification that uses within household variation also loses much of the useful between-village variation.
} 
have two pieces of suggestive evidence. First, we conducted a heterogeneous treatment effects analysis for households that are ex ante savings constrained versus households that are not. As discussed in Section 3.2, we expect stronger effects for households with below median retention rates (our proxy for households who are more likely savings constrained) because income effects are driven by expansions in the budget set. The magnitude of this expansion depends on differences between the baseline retention rates and $\bar{\gamma}$ (the retention rate under the new storage technology), where the improvement will be more significant for households with lower baseline retention rates. Indeed, Table A4 in the appendix shows that the effect is mostly concentrated amongst households who are ex ante savings constrained (the interaction terms with indicators for low-retention-rate households are statistically significant). ${ }^{38}$ We explain the heterogeneous treatment effect regressions in the appendix.

Second, we investigate another proxy for savings constraints-the need to contribute to neighbors' festival expenditures. Storage participants could circumvent this constraint by committing to store harvest for the lean season. To test this, we calculate the share of a household's annual festival expenditures that is used for neighbors' festivities. We find that storage participants report a $9 \%$ reduction in this share for all villages (though this is not significant) and a 22.2\% reduction in Alfa Omega villages (1\% sig.). This reduction for Alfa Omega villages is consistent with the mechanism described above, where commitment (formal or informal) associated with storage raised storage retention rates, $\gamma$.

\subsection{Cost benefit analysis}

We calculate the benefits-to-program cost ratio, which provides one way to compare our programs to others. Our preferred estimate for the numerator (benefits) is the annualized effect on consumption and income levels. This misses other effects (such as food shortages, health and seasonal smoothing effects) that are harder to monetize without estimating household preferences. However, it has the advantage of being transparent and comparable to other papers. For the denominator (program costs), our preferred estimate includes the average procurement costs per household (326,366 Rp for storage and 727,488 Rp for credit, as discussed in Section 4).

To calculate annualized benefits for storage, we use the result that storage had statistically significant effects on $\ln$ (Non-food expenditures) in both harvest and lean seasons (Table 2, Panel A). We repeated the exercise using monthly non-food expenditure levels for households (this includes observations with zero non-food expenditures, which is more conservative). The IV estimate of the treatment effect on monthly non-food expenditures for households is 70,000 Rp. ${ }^{39}$ The annualized benefit, then, is $(70,000$

\footnotetext{
${ }^{38}$ To construct baseline retention rates, we need pre-treatment data for both harvest and lean seasons (round 2 and round 3 for storage). We cannot construct baseline retention rates for credit since there is no pre-treatment harvest data.

${ }^{39}$ For the cost-effectiveness calculations, we use effects on consumption and income at the household level because the cost measures are calculated at the household level (we take total program costs divided
} 
$\mathrm{Rp}) * 2$ because expenditures increased statistically significantly for both harvest and lean season surveys, suggesting that, at minimum, the treatment effect led to improvements in two months per year.

Therefore, the benefit-to-cost ratio for storage, using annualized benefits and average procurement costs, is $43 \%(=140,000 \mathrm{Rp} / 326,366 \mathrm{Rp})$. This measure implies that improvements in monthly non-food expenditures would cover the upfront cost of the program used to purchase the storage equipment within 2.3 years.

For credit, the benefit-to-cost ratio is $53 \%$. Credit had a statistically significant effect on $\ln$ (Reported income) in the harvest season. The IV estimate of the treatment effect on quarterly household income is $389,000 \mathrm{Rp}$. Therefore, the benefit-to-cost ratio is $53 \%(=389,000 / 727,488)$, assuming the effect on income lasts only one quarter. This measure implies that improvements in quarterly household income would cover the upfront cost of the program used to purchase the seed capital within 1.9 years (calculated as 727,488/389,000).

A critical parameter is how sustainable our treatment effects are. The longer the benefits persist, the more we can amortize the upfront procurement costs, which would increase the benefit-to-cost ratios. One limitation of our study is that we only have surveys over a three-year span. Within our study period, our estimates suggest largely positive effects for each round of survey post treatment (but the standard errors are large if we do not pool the post treatment surveys). Moreover, the persistently high repayment rates (even when there were widespread harvest failures) suggest that the credit program can be sustainable over multiple years. Therefore, we make the conservative assumption that our programs' benefits persist for two years (because we only surveyed households for 2 years, post treatment). ${ }^{40}$ If we use annuitized procurement costs in the denominator, the benefit-to-cost ratios are $74 \%$ for storage and $93 \%$ for credit.

We benchmark these estimates against those for Raskin, a large rice subsidy program in Indonesia (discussed in Section 2). Tabor (2005) estimates that the transfer benefit per unit cost for Raskin is $52 \%$ for targeted beneficiaries. This assumes a leakage rate of $16 \%$. However, the The World Bank (2005) estimates that only $18 \%$ of the Raskin budget translates into a subsidy for poor households, suggesting a higher leakage rate. With a higher leakage rate, the benefit-to-cost ratio for Raskin would be lower than $52 \%$ because fewer benefits are reaching the targeted beneficiaries (the numerator is lower).

We also compared our estimates to other in-kind and cash transfer programs. Hoddinott, Skoufias, and Washburn (2000) report that consumption for Mexican households receiving Opportunidades benefits valued at 197 pesos per month increased by 151 pesos, translating to a benefit-to-cost ratio of $77 \%$. Importantly, rice subsidies,

by total number of participants, which is the total number of households since each household can only have one participant).

${ }^{40} \mathrm{We}$ calculated this by annuitizing the procurement costs reported above using a discount rate of $10 \%$ (a standard assumption in the literature). The annuitized procurement costs for storage and for credit were 188,049 Rp and 419,172 Rp per household, respectively. 
cash and in-kind transfers are financed by per-period costs (equivalent to the cost of the transfers) while our programs are financed from one-time costs to procure seed capital and storage equipment, which can be amortized over time if benefits are persistent.

In summary, our benefit-to-cost estimates for storage and credit are $43 \%$ and 53\% respectively. These numbers are comparable to the $52 \%$ estimate for Raskin and the $77 \%$ estimate for Opportunidades, except, the denominator of our benefit-to-cost ratios include one-time procurement costs. Amortizing procurement costs over 2 years (a conservative assumption) increases our benefit-to-cost ratios to $74 \%$ for storage and $93 \%$ for credit. $^{41}$

\section{Conclusion}

This paper focuses on the problem of seasonal food security for rural agricultural households. We use a simple consumption-savings model to frame the problem. Farmers with seasonal incomes must rely on savings or credit technologies to transfer assets across seasons. Under savings constraints (in kind and in cash) and credit constraints, the opportunity cost of lean season consumption is high. We describe this as a case of seasonal frictions, which are encapsulated by a harvest-to-lean season MRT of food that is smaller than one.

As described in Section 1, there are a number of potential ways to help households smooth consumption in the face of seasonal frictions. We propose and test two programs designed to raise the harvest-to-lean MRT, thereby subsidizing lean season consumption. By allowing households to either save more effectively (food storage) or borrow cheaply (food credit), the programs aimed to expand budget sets and improve the rate at which harvest season assets could be converted into lean season consumption. In this sense, our solutions can be viewed as addressing the basic problem of households lacking access to high MRT technologies for transferring food across seasons.

Our evaluation indicates improvements in economic well-being that are consistent with positive income effects arising from expanded budget sets. Both storage and credit led to increases in non-food consumption or reported income but had zero effects on staple consumption. Storage had no seasonal smoothing effects but credit did, though, under credit, health in the harvest season deteriorated moderately. Since the programs

\footnotetext{
${ }^{41}$ These ignore the annual implementation costs (mainly used to pay facilitators) discussed in Section 4. The annual implementation costs that are recurring include $254,803 \mathrm{Rp}$ for storage and $242,861 \mathrm{Rp}$ for credit. In practice, in the long run, these implementation costs would not be so high for storage once communities learn to use the storage equipment and for credit, the programs were designed so they could be easily added as a component of a national women's microcredit program (mentioned in Section 4.2). To be comprehensive, we also provide calculations that include implementation costs as well. Without amortization, if we include one-time procurement costs and annual implementation costs in the denominator, the benefit-to-cost ratios are $24 \%$ for storage $\left(=\frac{140,000}{326,366+254,803}\right)$ and $40 \%$ for credit. If we use annuitized procurement costs instead, the benefit-to-cost ratios are $32 \%$ for storage $\left(=\frac{140,000}{188,049+254,803}\right)$ and $59 \%$ for credit (where the denominator includes the annuitized procurement costs and the annual implementation costs).
} 
incur front-loaded costs and have recurring financial benefits, our cost-benefit analysis argues that they provide a cost-effective way to help farmers adapt to seasonality.

The food storage and food credit programs, when modified with caution, could inform food policy elsewhere. Rudimentary food storage technologies are prevalent in several agrarian economies, and the introduction of improved storage (used directly for storage programs or indirectly for credit programs, as discussed in Sections 3.2 and 4.1) could similarly expand budget sets for other poor households. Our research comes with some caveats and suggestions for ongoing investigation.

First, unlike regular subsidies on staples, these programs are of less immediate value to non-farming households whose incomes are not seasonal and not in kind. Unless such households could replicate the behavior of farming households by conducting basic transactions using staples, they cannot take advantage of the lean season subsidy implicit in storage and credit. This is because our programs have no direct effects on prices.

Second, our programs are expected to have persistent effects from the initial investments in storage equipment and seed capital. Since we have data spanning only three years, we are unable to measure persistence over a longer term. It is important to note that our cost structure is fundamentally different from that of regular price subsidies which incur recurring costs. As a result, a longer-term analysis would be expected to raise the implied cost-effectiveness of the programs.

Third, given the limited scale of our programs, we do not observe general equilibrium effects. A sufficiently large expansion of the programs should ultimately reduce the staple supply in the harvest season and raise the staple supply in the lean season. This will translate into a drop in lean season staple prices and a rise in harvest season staple prices. While these general equilibrium effects arise out of improved storage or credit markets, welfare effects for some households will be ambiguous. For example, consider a household that had access to a high-returns storage technology prior to the program and therefore did not experience a direct expansion of its budget set through food credit or food storage. In the short run, such a household will be unaffected by the programs. However, as a result of general equilibrium effects, since staples are expected to get cheaper in the lean season, lean season non-food consumption will get more expensive (relative to staples). If the household has a preference for lean season non-food consumption (that it funds through saved staples), it will be made worse off.

Fourth, we cannot rule out program effects on some forms of non-staple food consumption. In particular, recall that the credit program finds a rise in income with no discernible changes in consumption. Presumably the additional income translates into either forms of consumption that we do not measure (such as meat) or savings. It would be instructive to better understand where these changes lie.

Finally, it is interesting that the positive consumption and income effects of our programs are stronger in the harvest season. This is particularly noteworthy for credit, as it suggests households on average are not over-borrowing in a way that leaves them with little to consume after repayments in the harvest. It would be useful to learn how these results depend on time preferences or social or spousal pressures to share. For instance, 
do time-inconsistent agents borrow more in the lean season and save less in the harvest season? Existing theoretical and empirical work suggests that the impacts of savings and credit depend on time preferences in nuanced and sometimes unexpected ways. ${ }^{42}$ Given the encouraging results from our program evaluation, modified designs based on the preferences and other characteristics of target populations have the potential to substantially raise consumption and welfare.

${ }^{42}$ See Ashraf, Karlan, and Yin (2006); Basu (2014) 


\section{Acknowledgements}

We are indebted to Scott Guggenheim, Vic Bottini and Anton Tarigan for their support. We thank two referees and the editor for detailed comments. We also benefited from comments and support from Dewi Widuri, Pak Sentot Satria, Richard Manning, Junko Onishi, Ben Olken, Rob Jensen, Vijaya Mohan, Ela Hasanah, Natasha Hayward, Menno Pradhan, Pak Bakir Ali, Bill Ruscoe, Masayuki Kudamatsu, and seminar participants at Hunter College, Washington University of St. Louis, the Singapore Conference on Evidence-Based Public Policy Using Administrative Data, BREAD Conference on Development Economics and the Northeast Universities Development Consortium (NEUDC) conference. We thank Lembaga Penelitian of Universitas Nusa Cendana (led by Team Leader, Johanna Suek) for administering the survey. We thank our partners in the field, Yayasan Alfa Omega and Yayasan Tanaoba Lais Manekat. This pilot would not be possible without financial support from the Japanese Social Development Fund (TF090483 and TF091312). We thank the World Bank for permission to use the data. Views expressed do not necessarily reflect the opinions of the World Bank. Maisy Wong is grateful for financial support from the Zell-Lurie Real Estate Center. Lee Hye Jin and Chen Ying provided excellent research assistance. All errors remain ours. 


\section{References}

Ahmed, A. U., Quisumbing, A. R., Nasreen, M., Hoddinott, J. F., Bryan, E., 2010. Comparing Food and Cash Transfers to the Ultra-Poor in Bangladesh. Ifpri research monograph 163, Washington D.C.: IFPRI.

Alderman, H., Garcia, M., 1993. Poverty, Household Food Security, and Nutrition in Rural Pakistan. Research reports 96, International Food Policy Research Institute (IFPRI).

Alderman, H., Sahn, D. E., 1989. Understanding the Seasonality of Employment, Wages, and Incomes. In: Sahn, D. (Ed.), Seasonal Variability in Third World Agiculture. Johns Hopkins University Press, Baltimore, MD.

Angelucci, M., Attanasio, O., 2013. The Demand for Food of Poor Urban Mexican Households: Understanding Policy Impacts Using Structural Models. American Economic Journal: Economic Policy 5 (1), 146-205.

Ashraf, N., Karlan, D., Yin, W., 2006. Tying Odysseus to the Mast: Evidence from a Commitment Savings Product in the Philippines. The Quarterly Journal of Economics 121 (2), 635-672.

Attanasio, O., Battistin, E., Mesnard, A., 2012. Food and Cash Transfers: Evidence from Colombia. The Economic Journal 122 (559), 92-124.

Baland, J.-M., Guirkinger, C., Mali, C., 2011. Pretending to Be Poor: Borrowing to Escape Forced Solidarity in Cameroon. Economic Development and Cultural Change 60 (1), 1-16.

Banerjee, A. V., Duflo, E., 2007. The Economic Lives of the Poor. The Journal of Economic Perspectives 21 (1), 141-168.

Barrett, C., 2002. Food Security and Food Assistance Programs. Handbook of Agricultural Economics 2, 2103-2190.

Basu, K., 2014. Commitment Savings in Informal Banking Markets. Journal of Development Economics 107, 97-111.

Beaman, L., Karlan, D., Thuysbaert, B., 2009. Saving for Change. https://www.socialscienceregistry.org/trials/102.

Behrman, J., Foster, A., Rosenzweig, M., 1997. The Dynamics of Agricultural Production and the Calorie-Income Relationship. Journal of Econometrics 77 (1), 187-207.

Behrman, J. R., 1988. Nutrition, Health, Birth Order and Seasonality: Intrahousehold Allocation among Children in Rural India. Journal of Development Economics 28, 43-62. 
Besley, T., Kanbur, R., 1990. The Principles of Targeting. Policy Research Working Paper Series 385, The World Bank.

BPS, 2013. Penghitungan dan Analisis Kemiskinan Makro Indonesia Tahun 2013. Technical report, Badan Pusat Statistik (BPS)-Statistics Indonesia.

Bryan, G., Chowdhury, S., Mobarak, A. M., 2013. Escaping Famine through Seasonal Migration. Yale University Economic Growth Center Discussion Paper (1032).

Chaudhuri, S., Paxson, C., 2002. Smoothing Consumption Under Income Seasonality: Buyer Stocks vs. Credit Markets, Discussion Paper Series No. 0102-54, Department of Economics, Columbia University.

Deaton, A., 1991. Saving and Liquidity Constraints. Econometrica 59 (5), 1221-1248.

Devereux, S., Sabates-Wheeler, R., Longhurst, R., 2012. Seasonality, Rural Livelihoods and Development. Earthscan.

Devereux, S., Vaitla, B., Swan, S. H., 2008. Seasons of Hunger: Fighting Cycles of Starvations Among the World's Rural Poor. Pluto Press, London, UK.

Dréze, J., Sen, A., Hussain, A., 1995. The Political Economy of Hunger: Selected Essays. Oxford University Press, Oxford, UK.

FAO, 2003. Special Report, Crop and Food Supply Assessment Mission to Timore Leste. Food and Agriculture Organization and Food and United Nations World Food Programme.

FAO, 2013. The State of Food and Agriculture. Tech. rep., Food and Agriculture Organization.

Fox, J., 1977. Harvest of the Palm. Harvard University Press, Cambridge, MA.

Gelay, 2008. Rice Bank: Breaking the Poverty Cycle.

URL http://www.vast-bhutan.org/2008/06/19/rice-bank-breaking-thepoverty-cycle/

Handa, S., Mlay, G., 2006. Food Consumption Patterns, Seasonality and Market Access in Mozambique. Development Southern Africa 23 (4), 541-560.

Hidrobo, M., Hoddinott, J., Peterman, A., Margolies, A., Moreira, V., 2014. Cash, Food, or Vouchers? Evidence from a Randomized Experiment in Northern Ecuador. Journal of Development Economics 107, 144-156.

Hoddinott, J., Skoufias, E., Washburn, R., 2000. The impact of PROGRESA on consumption: A final report. Tech. rep., International Food Policy Research Institute.

Jensen, R., Miller, N., 2008. Giffen Behavior and Subsistence Consumption. American Economic Review 98 (4), 1553-1577. 
Jensen, R., Miller, N., 2010. A Revealed Preference Approach to Measuring Hunger and Undernutrition. NBER Working Paper No. W16555.

Jensen, R. T., Miller, N. H., 2011. Do Consumer Price Subsidies Really Improve Nutrition? Review of Economics and Statistics 93 (4), 1205-1223.

Jha, S., Ramaswami, B., 2010. How Can Food Subsidies Work Better? Answers from India and the Philippines. Economics Working Paper Series 221, Asian Development Bank.

Johnston, D., Morduch, J., 2008. The Unbanked: Evidence from Indonesia. The World Bank Economic Review 22 (3), 517-537.

Khandker, S., 2012. Seasonality of Income and Poverty in Bangladesh. Journal of Development Economics 97 (2), 244-256.

Khandker, S., Khaleque, M. A., Samad, H. A., 2011. Can Social Safety Nets Alleviate Seasonal Deprivation? Evidence from Northwest Bangladesh. World Bank Policy Research Working Paper Series (5865).

Khandker, S., Khalily, M., Samad, H. A., 2010. Seasonal and Extreme Poverty in Bangladesh: Evaluating an Ultra-Poor Microfinance Project. World Bank Policy Research Working Paper Series (5331).

Khandker, S. R., Mahmud, W., 2012. Seasonal Hunger and Public Policies: Evidence from Northwest Bangladesh. World Bank Publications, Washington, DC.

Kling, J. R., Liebman, J. B., 2004. Experimental Analysis of Neighborhood Effects on Youth, Princeton IRS Working Paper 483.

Kling, J. R., Liebman, J. B., Katz, L. F., 2007. Experimental Analysis of Neighborhood Effects. Econometrica 75 (1), 83-119.

Lines, T., 2011. The Potential Establishment of Emergency Food Reserve Funds. UNCTAD Special Unit on Commodities Working Paper Series on Commodities and Development Discussion paper, 3.

Mohan, V., Takada, M., Kalavakonda, V., Banerjee, S. S., Shah, P., 2007. Community Managed Food Security Enterprises in Andhra Pradesh, India. Tech. rep., Livelihoods Learning Series 1, Note 4. World Bank: Washington DC.

Olken, B., 2006. Corruption and the Costs of Redistribution:Micro Evidence from Indonesia. Journal of Public Economics 90 (4-5), 853-870.

Olken, B., 2007. Monitoring Corruption: Evidence from a Field Experiment in Indonesia. Journal of Political Economy 115 (2), 200-219. 
Paxson, C., 1993. Consumption and Income Seasonality in Thailand. Journal of Political Economy 101 (1), 39-72.

Pinstrup-Anderson, P., Jaramillo, M., 1989. The Impact of Drought and Technological Change in Rice Production on Intrayear Fluctuations in Food Consumption: The Case of North Arcot, India. In: Sahn, D. (Ed.), Seasonal Variability in Third World Agriculture. Johns Hopkins University Press, Baltimore, MD.

Pitt, M. M., Khandker, S. R., 2002. Credit Programmes for the Poor and Seasonality in Rural Bangladesh. Journal of Development Studies 39 (2), 1-24.

Sahn, D., 1989. Seasonal Variability in Third World Agriculture: the Consequences for Food Security. Baltimore: John Hopkins University Press.

Sen, A., 1981a. Ingredients of Famine Analysis: Availability and Entitlements. Quarterly Journal of Economics 96 (3), 433-464.

Sen, A., 1981b. Poverty and Famines: An Essay on Entitlement and Deprivation. Oxford University Press, New York, NY.

Tabor, S., 2005. RASKIN: Evolution of a Transfer Program. Technical report, The Bureau of Logistic Reports, Indonesia.

The World Bank, 2005. Feeding Indonesia. Technical report, The World Bank.

Townsend, R., 1994. Risk and Insurance in Village India. Econometrica 62 (3), 539591.

Trinugroho, I., Sutomo, Riani, A. L., 2011. The Efficiency of Public Service Obligation for Food Subsidy in Indonesia: Review of Cost Structure Analysis. Perspectives of Innovations, Economics \& Business 7, 45-47.

Zeller, M., 2001. The Safety Net Role of Microfinance for Income and Consumption Smoothing. In: Lustig, N. (Ed.), Shielding the Poor: Social Protection in the Developing World. Brookings Institution Press, pp. 217-238.

Zeller, M., Schrieder, G., von Braun, J., Heidhues, F., 1997. Rural Finance for Food Security of the Poor: Implications for Research and Policy. 


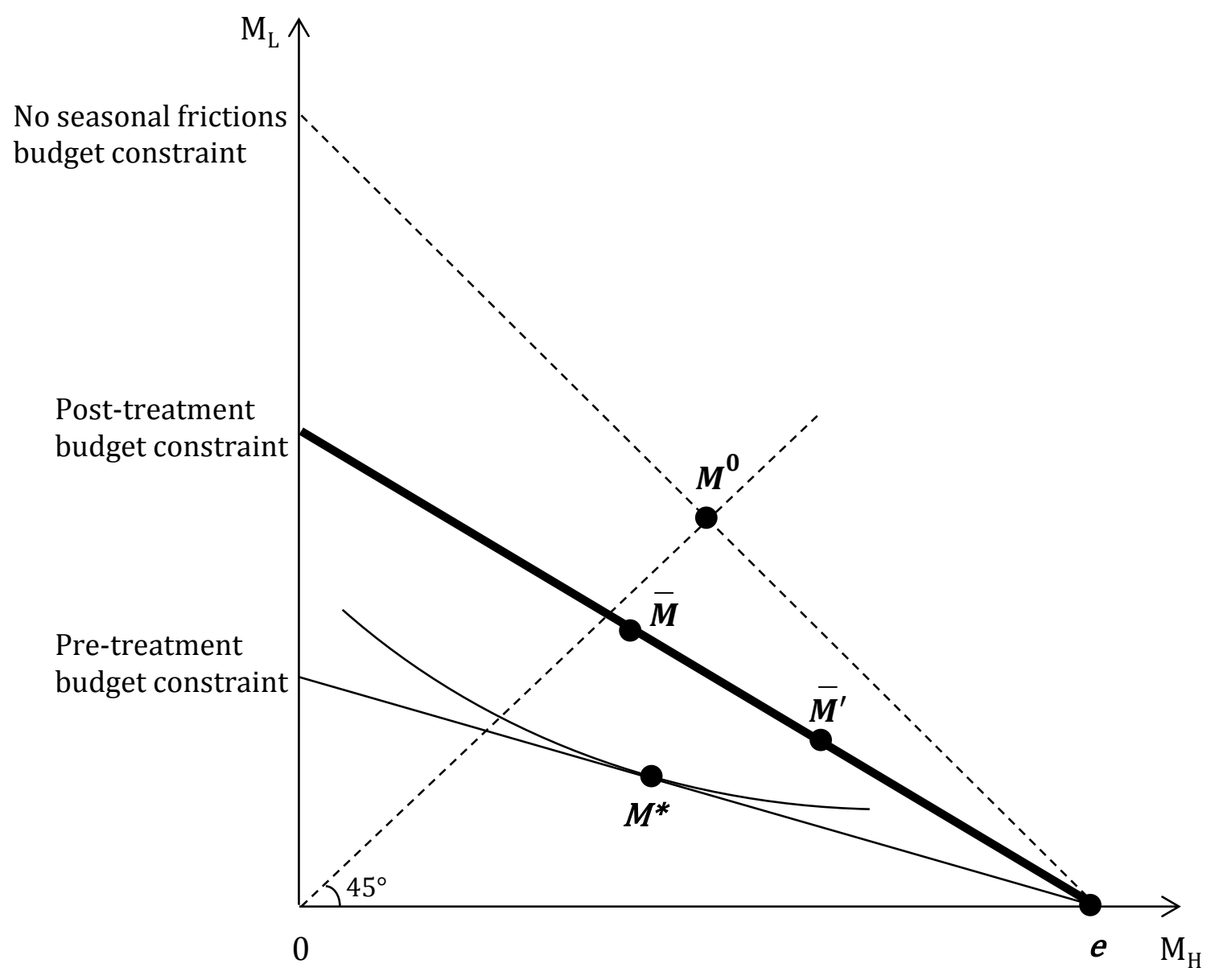

Figure 1: The inter-seasonal asset allocation problem. Assets (in staple units) allocated to harvest season consumption are on the x-axis and assets allocated to lean season consumption are on the $y$-axis, e is the endowment. $\mathrm{M}^{0}$ indicates the allocation if there are no seasonal frictions and utility functions are identical across seasons. $M^{*}$ is a hypothetical allocation under seasonal frictions. Possible post-treatment allocations are $\overline{\boldsymbol{M}}$ (if substitution effects dominate) and $\overline{\boldsymbol{M}}^{\prime}$ (if income effects dominate). 


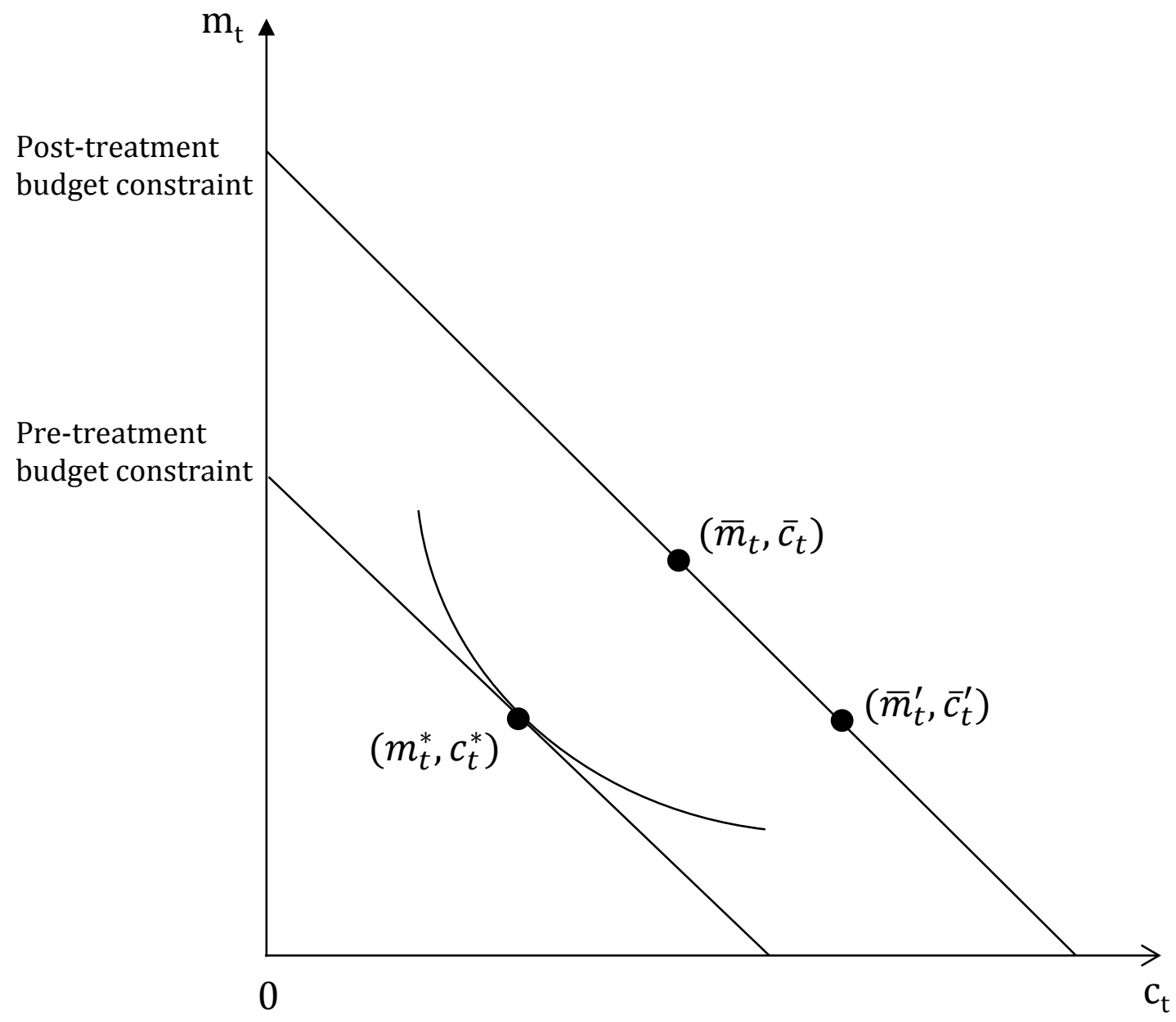

Figure 2: The within-season consumption problem. Assets available for consumption in season t must be allocated across staple food (y-axis) and non-food (x-axis). In autarky, the individual chooses $\left(\mathrm{m}^{*}{ }_{\mathrm{t}}, \mathrm{c}_{\mathrm{t}}{ }_{\mathrm{t}}\right)$. Suppose, as a result of the treatment, more assets are allocated to season $t$. The budget line shifts out. Possible post-treatment bundles are $\left(\bar{m}_{t}, \bar{c}_{t}\right)$ (homothetic utility) or $\left(\bar{m}_{t}^{\prime}, \bar{c}_{t}^{\prime}\right)($ staple satiation). 
Figure 3. Timeline of surveys and treatment by year and month

\begin{tabular}{|c|c|c|c|c|}
\hline & & Survey & Credit & Storage \\
\hline & & $(1)$ & $(2)$ & (3) \\
\hline \multirow[t]{12}{*}{ YEAR 1} & Sep '08 & Round 1 & & \\
\hline & Oct '08 & & & \\
\hline & Nov '08 & & & \\
\hline & Dec '08 & & Disbursement & \\
\hline & Jan '09 & & & \\
\hline & Feb '09 & & & \\
\hline & Mar '09 & & & \\
\hline & Apr '09 & & Repayment & \\
\hline & May '09 & & & \\
\hline & Jun '09 & & & \\
\hline & Jul '09 & Round 2 & & \\
\hline & Aug '09 & & & Distribute equipment \\
\hline \multirow[t]{12}{*}{ YEAR 2} & Sep '09 & & & \\
\hline & Oct '09 & & & \\
\hline & Nov '09 & Round 3 & & \\
\hline & Dec '09 & & Disbursement & \\
\hline & Jan'10 & & & \\
\hline & Feb '10 & & & \\
\hline & Mar '10 & & & \\
\hline & Apr '10 & & Repayment & \\
\hline & May '10 & & & \\
\hline & Jun '10 & & & \\
\hline & Jul '10 & Round 4 & & \\
\hline & Aug '10 & & & Distribute equipment \\
\hline \multirow[t]{9}{*}{ YEAR 3} & Sep '10 & & & \\
\hline & Oct '10 & & & \\
\hline & Nov'10 & Round 5 & & \\
\hline & Dec '10 & & Disbursement & \\
\hline & Jan'11 & & & \\
\hline & Feb '11 & & & \\
\hline & Mar '11 & & & \\
\hline & Apr '11 & Round 6 & & \\
\hline & May '11 & & & \\
\hline
\end{tabular}

Note: Months that are in italics (bold) correspond to the lean (harvest) season. 
Table 1: Baseline Summary Statistics and Balance Check

\begin{tabular}{|c|c|c|c|c|c|c|c|c|}
\hline & \multicolumn{2}{|c|}{ Control } & \multicolumn{3}{|c|}{ Storage-Control } & \multicolumn{3}{|c|}{ Credit-Control } \\
\hline & Mean & SD & Coeff. & p-value & $\mathrm{N}$ & Coeff. & p-value & $\mathrm{N}$ \\
\hline & (1) & (2) & (3) & (4) & (5) & (6) & (7) & (8) \\
\hline \multicolumn{9}{|l|}{ Panel A: Consumption and Income } \\
\hline$\overline{\text { Staple consumed, } \mathrm{kCal}}$ & 40.880 & 25.576 & -0.064 & 0.245 & 2147 & -0.063 & 0.261 & 1427 \\
\hline Non-food expenditure & 34.242 & 27.808 & 0.068 & 0.299 & 2145 & 0.073 & 0.311 & 1431 \\
\hline Reported income & 76.174 & 90.806 & 0.205 & 0.488 & 1970 & 0.270 & 0.377 & 1296 \\
\hline \multicolumn{9}{|c|}{ Panel B: Seasonal Differences, IHarvest - Leanl } \\
\hline Staple consumed, kCal & 24.520 & 33.102 & & & & & & \\
\hline Monthly non-food expenditure items & 10.406 & 13.709 & & & & & & \\
\hline Reported income & 80.726 & 108.684 & & & & & & \\
\hline \multicolumn{9}{|l|}{ Panel C: Food Shortages } \\
\hline$\overline{1 \text { (Anticipate food shortage in January) }}$ & 0.257 & 0.437 & 0.041 & 0.403 & 2150 & $0.095^{*}$ & 0.070 & 1433 \\
\hline 1(Anticipate food shor & 0.276 & 0.447 & 0.046 & 0.377 & 2150 & 0.089 & 0.101 & 1433 \\
\hline 1(Anticipate food shorta & 0.102 & 0.303 & 0.013 & 0.619 & 2150 & $0.070 * *$ & 0.047 & 1433 \\
\hline 1(Lacked food last month) & 0.590 & 0.492 & -0.027 & 0.598 & 2150 & 0.053 & 0.339 & 1433 \\
\hline \multicolumn{9}{|l|}{ Panel D: Health } \\
\hline 1(Health expenditure shortages) & 0.158 & 0.365 & 0.008 & 0.771 & 2150 & 0.005 & 0.856 & 1433 \\
\hline Number of sick days & 0.180 & 0.557 & 0.059 & 0.115 & 2150 & 0.022 & 0.550 & 1433 \\
\hline Number of sick household members & 0.024 & 0.050 & 0.004 & 0.331 & 2150 & 0.0004 & 0.925 & 1433 \\
\hline \multicolumn{9}{|l|}{ Panel E: Agricultural Yields and Storage } \\
\hline Amount of maize produced, $\mathrm{kg}$ & 145.137 & 179.054 & 7.662 & 0.717 & 2150 & -5.080 & 0.826 & 1433 \\
\hline Amount of maize stored, $\mathrm{kg}$ & 35.045 & 45.998 & -4.542 & 0.384 & 2150 & $-9.709 *$ & 0.069 & 1433 \\
\hline Amount of rice produced, $\mathrm{kg}$ & 132.165 & 282.393 & -11.229 & 0.729 & 2150 & -11.219 & 0.789 & 1433 \\
\hline Amount of rice stored, $\mathrm{kg}$ & 27.408 & 61.887 & -3.218 & 0.578 & 2150 & 3.987 & 0.666 & 1433 \\
\hline Ratio of maize stored & 0.287 & 0.481 & -0.017 & 0.596 & 1722 & $-0.057 *$ & 0.057 & 1145 \\
\hline Ratio of rice stored & 0.236 & 0.416 & -0.034 & 0.399 & 748 & -0.031 & 0.419 & 519 \\
\hline \multicolumn{9}{|l|}{ Panel F: Household Characteristics } \\
\hline$\overline{1(\text { Graduated primary school) }}$ & 0.780 & 0.415 & 0.00001 & 1.000 & 2150 & -0.007 & 0.826 & 1433 \\
\hline 1(Graduated lower secondary school) & 0.241 & 0.428 & 0.042 & 0.181 & 2150 & 0.0004 & 0.990 & 1433 \\
\hline Age & 44.800 & 12.564 & 0.445 & 0.591 & 2106 & 0.028 & 0.977 & 1403 \\
\hline Number of chickens owned & 3.116 & 3.584 & -0.123 & 0.653 & 2150 & -0.316 & 0.240 & 1433 \\
\hline Number of cows owned & 0.470 & 0.988 & -0.046 & 0.521 & 2150 & 0.077 & 0.379 & 1433 \\
\hline Number of pigs owned & 1.269 & 1.218 & $-0.178 *$ & 0.059 & 2150 & -0.005 & 0.969 & 1433 \\
\hline Number of motorcycles owned & 0.067 & 0.251 & $0.051 * * *$ & 0.008 & 2150 & 0.019 & 0.259 & 1433 \\
\hline Household size & 4.832 & 1.830 & -0.143 & 0.314 & 2150 & -0.030 & 0.854 & 1433 \\
\hline 1 (Has savings account in a bank) & 0.067 & 0.251 & -0.007 & 0.612 & 2150 & 0.003 & 0.810 & 1433 \\
\hline
\end{tabular}

$* \mathrm{p}<0.1, * * \mathrm{p}<0.05, * * * \mathrm{p}<0.01$

Notes-Columns 1 and 2 report means and standard deviations for control villages in the baseline. Columns 3 to 5 report results from an OLS regression comparing households in storage and control villages in the baseline, controlling for district fixed effects and clustering standard errors at the village level. Columns 3 and 4 report the coefficient and p-value corresponding to the storage dummy and column 5 reports the sample size for each regression. The full estimation sample for the storage versus control comparison includes 2150 households. Some dependent variables have missing values. Columns 6 to 8 report results comparing credit and control villages. The full estimation sample for the credit versus control comparison has 1433 households. In Panel A, we report means and standard deviations of consumption and income in levels (columns 1 and 2) but the regressions reported in columns 3 to 8 are in logs. All expenditure and income values are in thousands of Rupiahs (1 USD=9000 Rupiahs). All consumption and income variables in Panels A and B, as well as the last two health outcomes in Panel D, are in per capita per month units. 
Table 2: Impact of Storage and Credit on Outcomes

\begin{tabular}{|c|c|c|c|c|c|c|c|c|}
\hline \multirow{3}{*}{$\begin{array}{l}\text { Treatment: } \\
\text { Season: }\end{array}$} & \multicolumn{4}{|c|}{ Storage } & \multicolumn{4}{|c|}{ Credit } \\
\hline & All & Lean & Harvest & $\mathrm{N}($ All $)$ & All & Lean & Harvest & $\mathrm{N}($ All $)$ \\
\hline & (1) & (2) & (3) & (4) & (5) & (6) & (7) & $(8)$ \\
\hline \multicolumn{9}{|l|}{ Panel A: Consumption and Income } \\
\hline$\overline{\text { Consumption and Income Index }}$ & $\begin{array}{c}0.246^{* *} \\
(0.112)\end{array}$ & $\begin{array}{c}0.188 \\
(0.138)\end{array}$ & $\begin{array}{c}0.277 * * \\
(0.115)\end{array}$ & 5907 & $\begin{array}{c}0.164 \\
(0.107)\end{array}$ & $\begin{array}{c}0.013 \\
(0.116)\end{array}$ & $\begin{array}{c}0.267 * * \\
(0.126)\end{array}$ & 6565 \\
\hline $\log ($ Staple consumed, $\mathrm{kCal})$ & $\begin{array}{c}0.014 \\
(0.066)\end{array}$ & $\begin{array}{l}-0.034 \\
(0.103)\end{array}$ & $\begin{array}{c}0.039 \\
(0.068)\end{array}$ & 6009 & $\begin{array}{c}0.06 \\
(0.086)\end{array}$ & $\begin{array}{l}-0.067 \\
(0.103)\end{array}$ & $\begin{array}{c}0.145 \\
(0.109)\end{array}$ & 6741 \\
\hline $\log ($ Non-food expenditure) & $\begin{array}{c}0.324 * * \\
(0.135)\end{array}$ & $\begin{array}{l}0.311^{*} \\
(0.183)\end{array}$ & $\begin{array}{c}0.332 * * \\
(0.133)\end{array}$ & 6042 & $\begin{array}{c}0.12 \\
(0.124)\end{array}$ & $\begin{array}{l}-0.015 \\
(0.146)\end{array}$ & $\begin{array}{c}0.209 \\
(0.137)\end{array}$ & 6791 \\
\hline $\log ($ Reported income $)$ & $\begin{array}{c}0.515 \\
(0.339)\end{array}$ & $\begin{array}{c}0.431 \\
(0.272)\end{array}$ & $\begin{array}{c}0.56 \\
(0.456)\end{array}$ & 5943 & $\begin{array}{c}0.543 * * \\
(0.249)\end{array}$ & $\begin{array}{c}0.371 \\
(0.242)\end{array}$ & $\begin{array}{l}0.662^{*} \\
(0.347)\end{array}$ & 6615 \\
\hline \multicolumn{9}{|c|}{ Panel B: Seasonal Differences, |Harvest - Leanl } \\
\hline Seasonal Gap Index & $\begin{array}{l}-0.027 \\
(0.077)\end{array}$ & & & 1834 & $\begin{array}{l}-0.136 \\
(0.085)\end{array}$ & & & 2444 \\
\hline $\log ($ Staple consumed, $\mathrm{kCal})$ & $\begin{array}{c}0.016 \\
(0.074)\end{array}$ & & & 1909 & $\begin{array}{c}0.003 \\
(0.091)\end{array}$ & & & 2593 \\
\hline $\log ($ Monthly non-food expenditure items) & $\begin{array}{c}0.006 \\
(0.091)\end{array}$ & & & 1934 & $\begin{array}{c}-0.160 * * \\
(0.079)\end{array}$ & & & 2615 \\
\hline $\log ($ Reported income $)$ & $\begin{array}{l}-0.079 \\
(0.146)\end{array}$ & & & 1858 & $\begin{array}{c}-0.058 \\
(0.127)\end{array}$ & & & 2472 \\
\hline \multicolumn{9}{|l|}{ Panel C: Food Shortages } \\
\hline Food Shortage Index & $\begin{array}{l}-0.140 \\
(0.096)\end{array}$ & $\begin{array}{l}-0.306 \\
(0.195)\end{array}$ & $\begin{array}{l}-0.057 \\
(0.114)\end{array}$ & 6450 & $\begin{array}{l}-0.131 \\
(0.127)\end{array}$ & $\begin{array}{l}-0.014 \\
(0.169)\end{array}$ & $\begin{array}{l}-0.208 \\
(0.136)\end{array}$ & 7165 \\
\hline 1(Anticipate food shortage in January) & $\begin{array}{l}-0.033 \\
(0.076)\end{array}$ & $\begin{array}{l}-0.139 \\
(0.140)\end{array}$ & $\begin{array}{c}0.02 \\
(0.091)\end{array}$ & 6450 & $\begin{array}{l}-0.097 \\
(0.082)\end{array}$ & $\begin{array}{l}-0.043 \\
(0.112)\end{array}$ & $\begin{array}{l}-0.133^{*} \\
(0.080)\end{array}$ & 7165 \\
\hline 1(Anticipate food shortage in April) & $\begin{array}{l}-0.013 \\
(0.031)\end{array}$ & $\begin{array}{l}-0.063 \\
(0.039)\end{array}$ & $\begin{array}{c}0.012 \\
(0.032)\end{array}$ & 6450 & $\begin{array}{l}-0.022 \\
(0.030)\end{array}$ & $\begin{array}{c}0.01 \\
(0.045)\end{array}$ & $\begin{array}{l}-0.043 \\
(0.039)\end{array}$ & 7165 \\
\hline 1(Anticipate food shortage in November) & $\begin{array}{l}-0.089 * \\
(0.048)\end{array}$ & $\begin{array}{l}-0.123 \\
(0.106)\end{array}$ & $\begin{array}{l}-0.073 \\
(0.062)\end{array}$ & 6450 & $\begin{array}{l}-0.052 \\
(0.066)\end{array}$ & $\begin{array}{c}0.056 \\
(0.108)\end{array}$ & $\begin{array}{l}-0.124 * \\
(0.074)\end{array}$ & 7165 \\
\hline 1(Lacked food last month) & $\begin{array}{l}-0.079 \\
(0.061)\end{array}$ & $\begin{array}{l}-0.177^{*} \\
(0.099)\end{array}$ & $\begin{array}{c}-0.03 \\
(0.063)\end{array}$ & 6450 & $\begin{array}{c}-0.04 \\
(0.067)\end{array}$ & $\begin{array}{c}-0.08 \\
(0.075)\end{array}$ & $\begin{array}{l}-0.013 \\
(0.083)\end{array}$ & 7165 \\
\hline \multicolumn{9}{|l|}{ Panel D: Health } \\
\hline$\overline{\text { Health Index }}$ & $\begin{array}{l}-0.0002 \\
(0.074)\end{array}$ & $\begin{array}{c}0.134 \\
(0.084)\end{array}$ & $\begin{array}{l}-0.067 \\
(0.091)\end{array}$ & 6450 & $\begin{array}{c}-0.122 \\
(0.103)\end{array}$ & $\begin{array}{c}0.188 \\
(0.148)\end{array}$ & $\begin{array}{c}-0.330 * * * \\
(0.116)\end{array}$ & 7165 \\
\hline 1(Health expenditure shortages last month) & $\begin{array}{c}0.005 \\
(0.026)\end{array}$ & $\begin{array}{l}-0.053 \\
(0.038)\end{array}$ & $\begin{array}{c}0.034 \\
(0.027)\end{array}$ & 6450 & $\begin{array}{l}0.057^{*} \\
(0.032)\end{array}$ & $\begin{array}{l}-0.015 \\
(0.040)\end{array}$ & $\begin{array}{c}0.105^{* * *} * \\
(0.037)\end{array}$ & 7165 \\
\hline Number of sick days & $\begin{array}{c}0.033 \\
(0.589)\end{array}$ & $\begin{array}{l}-0.033 \\
(0.047)\end{array}$ & $\begin{array}{c}0.066 \\
(0.082)\end{array}$ & 6450 & $\begin{array}{c}0.047 \\
(0.092)\end{array}$ & $\begin{array}{l}-0.160 \\
(0.140)\end{array}$ & $\begin{array}{l}0.185^{*} \\
(0.104)\end{array}$ & 7165 \\
\hline Number of sick household members & $\begin{array}{l}-0.004 \\
(0.005)\end{array}$ & $\begin{array}{l}-0.010 \\
(0.008)\end{array}$ & $\begin{array}{l}-0.0005 \\
(0.005)\end{array}$ & 6450 & $\begin{array}{c}0.006 \\
(0.006)\end{array}$ & $\begin{array}{c}-0.012 \\
(0.008)\end{array}$ & $\begin{array}{c}0.018 * * * \\
(0.007)\end{array}$ & 7165 \\
\hline
\end{tabular}

$* \mathrm{p}<0.1, * * \mathrm{p}<0.05, * * * \mathrm{p}<0.01$

Notes-Column 1 reports the results from instrumental variable regressions where the main independent variable is a take-up dummy instrumented with the storage dummy, with district fixed effects and standard errors clustered at the village level. Column 1 pools all seasons, column 2 only includes lean season surveys and column 3 only includes harvest season surveys. Each pair of cells reports the coefficient estimate and standard error for the take-up dummy. The full estimation sample has 6450 observations, including households in storage and control villages from rounds 4 to 6 but the number of observations change for outcomes in logs, the sample sizes pooling all seasons are reported in column 4. Columns 5 to 8 report results for credit versus control villages. The full estimation sample has 7165 observations, including households in credit and control villages from rounds 2 to 6 . All expenditure and income values are in thousands of Rupiahs ( 1 USD=9000 Rupiahs). All consumption and income variables in Panels A and B, as well as the last two health outcomes in Panel D, are in per capita per month units. 
Table 3: Robustness Checks

\begin{tabular}{|c|c|c|c|c|c|c|c|c|}
\hline \multirow[t]{2}{*}{ Treatment: } & \multicolumn{4}{|c|}{ Storage } & \multicolumn{4}{|c|}{ Credit } \\
\hline & (1) & (2) & (3) & (4) & (5) & (6) & (7) & (8) \\
\hline \multicolumn{9}{|l|}{ Panel A: Consumption and Income } \\
\hline Consumption and Income Index & $\begin{array}{c}0.246^{* *} \\
(0.112)\end{array}$ & $\begin{array}{l}0.213^{*} \\
(0.115)\end{array}$ & $\begin{array}{l}0.198^{*} \\
(0.110)\end{array}$ & $\begin{array}{c}0.106 * * \\
(0.046)\end{array}$ & $\begin{array}{c}0.164 \\
(0.107)\end{array}$ & $\begin{array}{c}0.130 \\
(0.114)\end{array}$ & $\begin{array}{c}0.113 \\
(0.111)\end{array}$ & $\begin{array}{c}0.067 \\
(0.044)\end{array}$ \\
\hline $\log ($ Staple consumed, $\mathrm{kCal})$ & $\begin{array}{c}0.014 \\
(0.066)\end{array}$ & $\begin{array}{c}0.034 \\
(0.066)\end{array}$ & $\begin{array}{c}0.027 \\
(0.071)\end{array}$ & $\begin{array}{c}0.006 \\
(0.029)\end{array}$ & $\begin{array}{c}0.060 \\
(0.086)\end{array}$ & $\begin{array}{c}0.082 \\
(0.086)\end{array}$ & $\begin{array}{c}0.056 \\
(0.087)\end{array}$ & $\begin{array}{c}0.024 \\
(0.036)\end{array}$ \\
\hline $\log$ (Non-food expenditure, in $1000 \mathrm{Rp}$ ) & $\begin{array}{c}0.324 * * \\
(0.135)\end{array}$ & $\begin{array}{c}0.276 * * \\
(0.116)\end{array}$ & $\begin{array}{c}0.267 * * \\
(0.112)\end{array}$ & $\begin{array}{c}0.139 * * \\
(0.054)\end{array}$ & $\begin{array}{c}0.120 \\
(0.124)\end{array}$ & $\begin{array}{c}0.070 \\
(0.110)\end{array}$ & $\begin{array}{c}0.061 \\
(0.115)\end{array}$ & $\begin{array}{c}0.049 \\
(0.050)\end{array}$ \\
\hline Log(Reported income) & $\begin{array}{c}0.515 \\
(0.339)\end{array}$ & $\begin{array}{c}0.487 \\
(0.353)\end{array}$ & $\begin{array}{c}0.462 \\
(0.336)\end{array}$ & $\begin{array}{c}0.221 \\
(0.144)\end{array}$ & $\begin{array}{c}0.543 * * \\
(0.249)\end{array}$ & $\begin{array}{l}0.526^{* *} \\
(0.263)\end{array}$ & $\begin{array}{l}0.487^{*} \\
(0.266)\end{array}$ & $\begin{array}{l}0.221 * * \\
(0.103)\end{array}$ \\
\hline \multicolumn{9}{|c|}{ Panel B: Seasonal Differences, |Harvest - Lean| } \\
\hline Seasonal Gap Index & $\begin{array}{l}-0.027 \\
(0.077)\end{array}$ & & & $\begin{array}{l}-0.012 \\
(0.034)\end{array}$ & $\begin{array}{l}-0.136 \\
(0.085)\end{array}$ & & & $\begin{array}{l}-0.057 \\
(0.035)\end{array}$ \\
\hline Log(Staple consumed, kCal) & $\begin{array}{c}0.016 \\
(0.074)\end{array}$ & & & $\begin{array}{c}0.007 \\
(0.033)\end{array}$ & $\begin{array}{c}0.003 \\
(0.091)\end{array}$ & & & $\begin{array}{c}0.001 \\
(0.038)\end{array}$ \\
\hline Log(Monthly non-food expenditure items) & $\begin{array}{c}0.006 \\
(0.091)\end{array}$ & & & $\begin{array}{c}0.003 \\
(0.040)\end{array}$ & $\begin{array}{c}-0.160 * * \\
(0.079)\end{array}$ & & & $\begin{array}{c}-0.066^{* * *} \\
(0.032)\end{array}$ \\
\hline Log(Reported income) & $\begin{array}{l}-0.079 \\
(0.146)\end{array}$ & & & $\begin{array}{l}-0.035 \\
(0.064)\end{array}$ & $\begin{array}{l}-0.058 \\
(0.127)\end{array}$ & & & $\begin{array}{l}-0.024 \\
(0.054)\end{array}$ \\
\hline \multicolumn{9}{|l|}{ Panel C: Food Shortages } \\
\hline$\overline{\text { Food Shortage Index }}$ & $\begin{array}{l}-0.140 \\
(0.096)\end{array}$ & $\begin{array}{l}-0.138 \\
(0.096)\end{array}$ & $\begin{array}{l}-0.130 \\
(0.093)\end{array}$ & $\begin{array}{l}-0.058 \\
(0.041)\end{array}$ & $\begin{array}{l}-0.131 \\
(0.127)\end{array}$ & $\begin{array}{l}-0.139 \\
(0.126)\end{array}$ & $\begin{array}{l}-0.138 \\
(0.116)\end{array}$ & $\begin{array}{l}-0.052 \\
(0.052)\end{array}$ \\
\hline 1(Anticipate food shortage in January) & $\begin{array}{l}-0.033 \\
(0.076)\end{array}$ & $\begin{array}{l}-0.032 \\
(0.076)\end{array}$ & $\begin{array}{l}-0.023 \\
(0.074)\end{array}$ & $\begin{array}{l}-0.014 \\
(0.032)\end{array}$ & $\begin{array}{l}-0.097 \\
(0.082)\end{array}$ & $\begin{array}{l}-0.099 \\
(0.082)\end{array}$ & $\begin{array}{l}-0.101 \\
(0.077)\end{array}$ & $\begin{array}{l}-0.038 \\
(0.034)\end{array}$ \\
\hline 1(Anticipate food shortage in April) & $\begin{array}{l}-0.013 \\
(0.031)\end{array}$ & $\begin{array}{l}-0.011 \\
(0.030)\end{array}$ & $\begin{array}{l}-0.012 \\
(0.031)\end{array}$ & $\begin{array}{l}-0.005 \\
(0.013)\end{array}$ & $\begin{array}{l}-0.022 \\
(0.030)\end{array}$ & $\begin{array}{l}-0.023 \\
(0.030)\end{array}$ & $\begin{array}{l}-0.025 \\
(0.030)\end{array}$ & $\begin{array}{l}-0.009 \\
(0.012)\end{array}$ \\
\hline 1(Anticipate food shortage in November) & $\begin{array}{l}-0.089^{*} \\
(0.048)\end{array}$ & $\begin{array}{c}-0.089^{*} \\
(0.048)\end{array}$ & $\begin{array}{l}-0.087^{*} \\
(0.048)\end{array}$ & $\begin{array}{l}-0.037^{*} \\
(0.020)\end{array}$ & $\begin{array}{l}-0.052 \\
(0.066)\end{array}$ & $\begin{array}{l}-0.052 \\
(0.066)\end{array}$ & $\begin{array}{l}-0.052 \\
(0.062)\end{array}$ & $\begin{array}{l}-0.021 \\
(0.027)\end{array}$ \\
\hline 1(Lacked food last month) & $\begin{array}{l}-0.079 \\
(0.061)\end{array}$ & $\begin{array}{l}-0.078 \\
(0.060)\end{array}$ & $\begin{array}{l}-0.075 \\
(0.059)\end{array}$ & $\begin{array}{l}-0.033 \\
(0.026)\end{array}$ & $\begin{array}{l}-0.040 \\
(0.067)\end{array}$ & $\begin{array}{l}-0.043 \\
(0.067)\end{array}$ & $\begin{array}{l}-0.040 \\
(0.065)\end{array}$ & $\begin{array}{l}-0.016 \\
(0.027)\end{array}$ \\
\hline \multicolumn{9}{|l|}{ Panel D: Health } \\
\hline Health Index & $\begin{array}{l}-0.0002 \\
(0.074)\end{array}$ & $\begin{array}{c}0.011 \\
(0.071)\end{array}$ & $\begin{array}{c}0.026 \\
(0.070)\end{array}$ & $\begin{array}{c}-0.00008 \\
(0.031)\end{array}$ & $\begin{array}{l}-0.122 \\
(0.103)\end{array}$ & $\begin{array}{l}-0.119 \\
(0.100)\end{array}$ & $\begin{array}{l}-0.110 \\
(0.098)\end{array}$ & $\begin{array}{l}-0.048 \\
(0.041)\end{array}$ \\
\hline 1(Health expenditure shortages last month) & $\begin{array}{c}0.005 \\
(0.026)\end{array}$ & $\begin{array}{c}0.005 \\
(0.026)\end{array}$ & $\begin{array}{c}0.010 \\
(0.025)\end{array}$ & $\begin{array}{c}0.002 \\
(0.011)\end{array}$ & $\begin{array}{l}0.057 * \\
(0.032)\end{array}$ & $\begin{array}{l}0.057 * \\
(0.031)\end{array}$ & $\begin{array}{c}0.064 * * \\
(0.032)\end{array}$ & $\begin{array}{l}0.023^{*} \\
(0.012)\end{array}$ \\
\hline Number of sick days & $\begin{array}{c}0.033 \\
(0.059)\end{array}$ & $\begin{array}{c}0.022 \\
(0.056)\end{array}$ & $\begin{array}{c}0.001 \\
(0.056)\end{array}$ & $\begin{array}{c}0.014 \\
(0.025)\end{array}$ & $\begin{array}{c}0.047 \\
(0.092)\end{array}$ & $\begin{array}{c}0.044 \\
(0.090)\end{array}$ & $\begin{array}{c}0.036 \\
(0.085)\end{array}$ & $\begin{array}{c}0.019 \\
(0.037)\end{array}$ \\
\hline Number of sick household members & $\begin{array}{l}-0.004 \\
(0.005)\end{array}$ & $\begin{array}{c}-0.004 \\
(0.005)\end{array}$ & $\begin{array}{l}-0.005 \\
(0.004)\end{array}$ & $\begin{array}{c}-0.002 \\
(0.002)\end{array}$ & $\begin{array}{c}0.006 \\
(0.006)\end{array}$ & $\begin{array}{c}0.006 \\
(0.005)\end{array}$ & $\begin{array}{c}0.005 \\
(0.005)\end{array}$ & $\begin{array}{c}0.003 \\
(0.002)\end{array}$ \\
\hline Estimation & IV & IV & IV & OLS & IV & IV & IV & OLS \\
\hline Dependant variable (round 1) & No & Yes & Yes & No & No & Yes & Yes & No \\
\hline Demographics (round 1) & No & No & Yes & No & No & No & Yes & No \\
\hline
\end{tabular}

$* \mathrm{p}<0.1, * * \mathrm{p}<0.05, * * * \mathrm{p}<0.01$

Notes-Column 1 is the same as column 1 in Table 2 (our main IV estimates for storage). Column 2 controls for baseline values of the dependent variable. Column 3 adds baseline values of demographics reported in Panel F in Table 1. Each pair of cells reports the coefficient estimate and standard error for the take-up dummy. Column 4 reports OLS coefficient estimates for the treatment dummy. Columns 5 to 8 report robustness checks for credit. The full estimation samples for storage are 6450 (columns 1, 2 and 4) and 6318 (column 3) because we dropped some observations with no age information. For credit, the full estimation samples are 7165 (columns 5, 6, and 8) and 7,015 (column 7), when we control for baseline demographics. All expenditure and income values are in thousands of Rupiahs (1 USD=9000 Rupiahs). All consumption and income variables in Panels A and B, as well as the last two health outcomes in Panel D, are in per capita per month units. 
Table 4: Other Budget Set Items

\begin{tabular}{lcccc}
\hline Outcome: & Gifts & Remittances & Wage & Household size \\
\cline { 2 - 5 } & $(1)$ & $(2)$ & $(3)$ & $(4)$ \\
\hline $\begin{array}{lcccc}\text { Panel A: Storage } \\
\text { 1(Take-up) }\end{array}$ & 1.601 & -0.308 & 6.989 & -0.137 \\
& $(4.740)$ & $(3.959)$ & $(11.117)$ & $(0.351)$ \\
\hline $\mathrm{N}$ & 6450 & 6450 & 6450 & 6450 \\
\hline Panel B: Credit & 1.395 & -2.742 & -0.241 & -0.058 \\
\hline (Take-up) & $(4.208)$ & $(3.128)$ & $(8.853)$ & $(0.386)$ \\
\hline $\mathrm{N}$ & 7165 & 7165 & 7165 & 7165 \\
\hline
\end{tabular}

$* \mathrm{p}<0.1, * * \mathrm{p}<0.05, * * * \mathrm{p}<0.01$

Notes-This table repeats the IV estimation in column 1 of Table 2 (for storage, Panel A) and column 5 of Table 2 (for credit, Panel B). Each column is a regression where the dependent variable is reported in the column header. The sample sizes for each regression are reported in the bottom of the panel.The dependent variables for columns 1 to 3 are the per capita per month transfers, remittances and wages (in thousands of Rupiahs) reported by the household (including zero's). In column 4, household size is the number of household members. 


\title{
Evaluating Seasonal Food Security Programs in East Indonesia (Appendix)
}

\author{
Karna Basu and Maisy Wong
}

February 26, 2014

\section{Data}

\subsection{Describing the sample}

In total, we sampled 2,877 households, followed over six survey rounds (odd rounds are lean season surveys and even rounds are harvest season surveys). Of these households, 720 were in credit villages, 1,440 were in storage villages (half were in pure and half in contract storage) and 717 were in control villages. There was no attrition. So, in total, we have 17,262 (calculated as 2,877 times 6) observations at the household-by-survey-round level.

We surveyed 30 households out of two hamlets per village in 96 villages. Hamlets within each village tended to be far apart so our survey team could only focus on surveying households in 2 hamlets per village. To increase the percent of surveyed households who would be offered treatment, we first instructed the survey team to select 30 households randomly within 2 hamlets in both the treatment and control villages. Then, we instructed the facilitators to offer all survey respondents in each village the option to participate. Since the selection of survey respondents was independent of the selection of program participants, the respondents in the treatment and control villages are still comparable, on average.

Our estimation sample includes 2,870 households ( 713 from control villages, 720 from credit villages and 1,437 from storage villages). We dropped 7 households because we were not able to use their ID in the household questionnaire to merge with any of the six rounds of individual questionnaires. Consequently, we do not have data on the demographics of these households and the number of household members (which we need to construct per capita variables).

Here are the number of observations for the main estimation samples:

- For the storage versus control villages comparison, the baseline regression (Table 1, column 5) includes 2150 observations (unless there are missing values, discussed below). For credit, we have 1433 observations (Table 1, column 8).

- The IV estimation for storage that pools all post-treatment surveys (rounds 4 to 6). It is reported in Table 2 (columns 1 and 4) and has $\underline{6450}$ observations (calculated as $1437+713$ households times 3 survey rounds). The IV estimation for credit pools rounds 2 to 6 . It is reported in Table 2 (columns 5 and 8) and has $\underline{7165}$ observations (calculated as 720+713 households times 5 survey rounds). 


\subsection{Defining key variables}

We designed the survey in consultation with researchers from the local agricultural institute, who conducted the survey. Whenever possible, the survey questions were taken directly from Indonesia's annual household survey, Susenas. We pre-tested the survey questions and made slight modifications to adjust for local crops and staples. In Table A1, we describe how each variable in Table 1 was constructed.

\subsection{Data issues}

- Outliers: All measures related to income, consumption, production, storage and assets have been winsorized at the top $2 \%$ to minimize biases due to outliers. We also tried winsorizing at the top 5\% and the results are similar.

- Calculating per capita per month values: To calculate per capita values we divided by number of household members in the contemporaneous survey round. For some household-by-survey round observations, we filled in the missing values for household size with the mean for that household (calculated using other survey rounds with non-missing values). To convert weeks to months, we multipled the total by 4 .

- Potential bias due to missing values: As discussed above, the IV estimation sample for the storage versus control comparison includes 6,450 observations and the estimation sample for the credit versus control comparison includes 7,165 observations. However, Panels A and B show that there are missing values because we take logs. Notably, the summary index (first row in each panel) is only defined if all outcomes used to calculate the index are nonmissing. To check that the censoring due to logs is not driving the results, we also report results that drop all observations where any of the logged outcomes are missing (about 8\% of the sample). We end up with 5907 observations for storage and 6565 observations for credit. As shown in Table A2, the results are broadly similar. There is still a zero effect on staple consumption, and sizeable increases in non-food expenditure for storage and increases in reported income for credit. The reduction in the seasonal difference in monthly non-food expenditure items remain for credit so do the health effects, with similar magnitudes. 


\section{Other results}

\subsection{Pure versus absolute seasonal differences}

We chose to use absolute differences $(\mid$ Harvest - Lean $\mid)$ instead of pure differences $(($ Harvest Lean)) because we are interested in testing whether the treatments reduced the magnitude of the seasonal gap between harvest and lean seasons for the average household in the treated village. There are two advantages to using absolute differences. First, we did not want households with positive pure differences to cancel out households with negative pure differences as we average across households' seasonal differences in a village. Taking absolute seasonal gaps would add both positive and negative seasonal differences.

Second, a significant number of households in our sample have negative pure differences, ${ }^{1}$ and for these households, a further reduction in the pure difference (by transferring from the harvest to the lean season) may not be a welfare improvement. The interpretation depends on whether the reduction in pure differences comes from preferences or from adverse shocks.

While the absolute difference in consumption across seasons is not independently a measure of welfare, it can be interpreted in conjunction with overall levels of consumption. In particular, suppose utility functions are concave, identical and separable across seasons. Then, a reduction of the absolute seasonal difference can be interpreted as a rise in welfare if total annual consumption remains the same. In Figure 1, this means that along any inter-seasonal budget constraint with a slope of -1 (all bundles along this line have the same total consumption levels, i.e. $M_{H}+M_{L}$ is constant), consumption bundles closer to the 45-degree line are associated with higher indifference curves. Nevertheless, for completeness, we also report the results using pure differences in Table A3. None of the coefficients have p-values at or below $5 \%$. The difference for staple consumption is positive, but only significant at the $10 \%$ level.

\subsection{Heterogeneous treatment effects}

We calculated the baseline retention rate using the total amount or rice and maize in stock in round 3 (lean) divided by the total amount of rice and maize in stock in round 2 (previous harvest). Then, we created an indicator for households' whose retention rate is below the median. Since retention rates are ratios, we had to drop some households that reported zero yield (the denominator) in round 2.

To estimate whether treatment effects differed by retention rates, we repeat Equation (6) but add two regressors: the indicator for households with below median retention rates and its interaction with the take-up dummy (where the interaction is instrumented by the interaction with the treatment dummy). Incidentally, we cannot construct baseline retention rates for credit households because we need a harvest and a lean season survey within the same agricultural cycle that is before treatment (rounds 2 and 3 for storage, but none exist for credit).

Table A4 in the appendix reports IV estimates of these heterogeneous treatment effects. The column labeled, N(All) reports sample sizes for the regression using all seasons. In the same column, the p-values in brackets correspond to the test of a zero treatment effect for low gamma households (we test whether the sum of the coefficients on the take-up dummy and the interaction

\footnotetext{
${ }^{1}$ In our control group, close to half of the households have larger staple consumption or non-food expenditures in the lean season than the harvest season (so, the pure difference of harvest minus lean is negative).
} 
term is zero, using the estimation sample that pools both seasons). The results show that most of the effects reported in Table 2 on consumption appear to be concentrated amongst households with low baseline retention rates (it is the coefficient on the interaction term that is positive and statistically significant). This is in line with our theory that the storage treatment expanded the budget set, with a more significant improvement for households with low baseline retention rates. 


Variable
$\frac{\text { Panel A: Consumption and Income }}{\text { Log(Staple consumed, } \mathrm{kCal})}$

Log(Staple consumed, kCal)

Log(Non-food expenditure)

\section{Log(Reported income)}

$\frac{\text { Panel B: Seasonal Differences }}{\text { Log(Staple consumed, kCal) }}$

og(Monthly non-food expenditure items)

\section{Panel C: Food Shortages}

1(Anticipate food shortages in January)

1(Anticipate food shortages in April)

1(Anticipate food shortages in November)

1(Lacked food last month)

Panel D: Health

1(Health expenditure shortages)

Number of sick days

Number of sick household members

Panel E: Agricultural Yields and Storage Amount of maize produced, $\mathrm{kg}$ Amount of maize stored, $\mathrm{kg}$ Amount of rice produced, $\mathrm{k}$ Amount of rice stored,
Ratio of rice stored Ratio of maize stored

Panel F: Household Characteristics

1(Graduated primary school)

1(Graduated lower secondar school)

Age of household head

Number of chickens owned

Number of cows owned

Number of motorcycles owned

Household size

1 (Has savings in a bank)
Data construction

Survey Question

Survey

Calculated as Ln [(Rice consumed in $\mathrm{kg} * 3.6 * 4+$ Maize consumed in $\mathrm{kg} * 3.56 * 4) /($ Number of household members)]. To convert kilograms to calories, we used rates available at http://www.fao.org/docrep/x5557e/x5557e04.htm\#cereals. For rice, we used $100 \mathrm{~g}$ to 360 calories (the rate for milled, white rice) andfor maize, we used $100 \mathrm{~g}$ to 356 calories (the rate for grain or whole meall.

Calculated as Ln [(Monthly expenditure items)+(Seasonal expenditures/6)+(Annual expenditures/12)]/(Number of household members)]

Amount of rice and maize consumed in the past week.

Household

We used the non-food expenditure module from Susenas. We asked households for monthly expenditure items (including rent, utilities, personal expendutires such as soap, make up and phonecards, heath expenditures and health insurance costs), seasonal expenditures (including festival expenditures for own and others, including weddings, birthdays, religious ceremonies, traditional ceremonies and other festivities) and annual expenditure items (including education expenditures, clothing, durables, taxes).

We asked for the reported income in the past 3 months, including income from the sale of Household agricultural output, wages, remittance and other receipts.

Household

Calculated as Ln (Quarterly reported income/(3*Number of household members)

Absolute difference of round 2 minus round 3 (for first agricultural cycle) and absolute difference of round 4 minus round 5 (for second agricultural cycle).

Only includes monthly expenditure items (including rent, utilities, personal expendutires such as soap, make up and phonecards, health expenditures and health insurance costs).

\section{$1($ Response $=$ No)}

$1($ Response $=$ No $)$

$1($ Response $=$ No)

$1($ Response $=$ Yes $)$

Do you think you can afford to buy food for the following January?

Do you think you can afford to buy food for the following April?

Do you think you can afford to buy food for the following November?

Have you lacked food in the last month?

Did you have problems paying health expenses the last month?

1 (Response $=$ Yes $)$

Calculated as the total number of sick days for the entire household, including zeros for

households who were not sick, divided by (the total number of household members times 3 ) to were affected?

obtain per capita per month units.

hof households who reported any sickness in the past 3 months Which household members were sick the last 3 months?

divided by total number of household members times 3 to obtain per capita per month units.

Total maize produced.

Total maize in storage.

Total rice produced.

Total rice in storage.

Total rice in storage/total rice produced

Total maize in storage/total maize produced

1 (Household head completed primary school or more)

1 (Household head completed lower secondary school or more)

Year of survey - year of birth

Number of chickens owned

Number of cows owned

Number of motorcycles owned

Number of household members

1 if the household reports having savings in a bank
In the previous harvest season how much of maize did you produce (in $\mathrm{kg}$ )? In the past 3 months, what is the amount of maize in storage now (in $\mathrm{kg}$ )? In the previous harvest season, how much of rice did you produce (in $\mathrm{kg}$ )? in the past 3 months, what is the amount of rice in storage now (in kg)? Amount of rice stored, divided by amount of rice produced (in $\mathrm{kg}$ ) Amount of maize stored, divided by amount of maize produced (in $\mathrm{kg}$ )

What is the highest education achieved? (Response: 02 Primary education) What is the highest education achieved? (Response: 03 Lower secondary education) What is the year of birth?

How of chickens do you own?

How

How of pigs do you own?

How of motorcycles do you own?
Household Household Household Household

Household Household Household

tousenold

Household Household Household Household Household
Household

Individual Individual Individual Household Household Household Household Household Individual 
Table A2: Missing outcomes

\begin{tabular}{|c|c|c|c|c|c|c|c|c|}
\hline \multirow{3}{*}{$\begin{array}{l}\text { Treatment: } \\
\text { Season: }\end{array}$} & \multicolumn{4}{|c|}{ Storage } & \multicolumn{4}{|c|}{ Credit } \\
\hline & All & Lean & Harvest & $\mathrm{N}(\mathrm{All})$ & All & Lean & Harvest & $\mathrm{N}(\mathrm{All})$ \\
\hline & (1) & (2) & (3) & (4) & $(5)$ & (6) & (7) & $(8)$ \\
\hline \multicolumn{9}{|l|}{ Panel A: Consumption and Income } \\
\hline$\overline{\text { Consumption and Income Index }}$ & $\begin{array}{c}0.246^{* *} \\
(0.112)\end{array}$ & $\begin{array}{c}0.188 \\
(0.138)\end{array}$ & $\begin{array}{c}0.277 * * \\
(0.115)\end{array}$ & 5907 & $\begin{array}{c}0.164 \\
(0.107)\end{array}$ & $\begin{array}{c}0.013 \\
(0.116)\end{array}$ & $\begin{array}{c}0.267 * * \\
(0.126)\end{array}$ & 6565 \\
\hline $\log ($ Staple consumed, $\mathrm{kCal})$ & $\begin{array}{c}0.017 \\
(0.066)\end{array}$ & $\begin{array}{c}-0.04 \\
(0.101)\end{array}$ & $\begin{array}{c}0.045 \\
(0.069)\end{array}$ & 5907 & $\begin{array}{c}0.044 \\
(0.082)\end{array}$ & $\begin{array}{l}-0.068 \\
(0.102)\end{array}$ & $\begin{array}{c}0.12 \\
(0.103)\end{array}$ & 6565 \\
\hline $\log$ (Non-food expenditure, in $1000 \mathrm{Rp})$ & $\begin{array}{c}0.337 * * \\
(0.132)\end{array}$ & $\begin{array}{l}0.312^{*} \\
(0.177)\end{array}$ & $\begin{array}{c}0.352^{* * * *} \\
(0.131)\end{array}$ & 5907 & $\begin{array}{c}0.12 \\
(0.119)\end{array}$ & $\begin{array}{l}-0.014 \\
(0.141)\end{array}$ & $\begin{array}{c}0.209 \\
(0.133)\end{array}$ & 6565 \\
\hline $\log ($ Reported income $)$ & $\begin{array}{c}0.514 \\
(0.338)\end{array}$ & $\begin{array}{c}0.427 \\
(0.269)\end{array}$ & $\begin{array}{c}0.56 \\
(0.455)\end{array}$ & 5907 & $\begin{array}{c}0.536^{* *} \\
(0.247)\end{array}$ & $\begin{array}{c}0.379 \\
(0.239)\end{array}$ & $\begin{array}{l}0.646^{*} \\
(0.344)\end{array}$ & 6565 \\
\hline \multicolumn{9}{|c|}{ Panel B: Seasonal Differences, |Harvest - Lean| } \\
\hline Seasonal Gap Index & $\begin{array}{c}-0.027 \\
(0.077)\end{array}$ & & & 1834 & $\begin{array}{l}-0.136 \\
(0.085)\end{array}$ & & & 2444 \\
\hline $\log ($ Staple consumed, $\mathrm{kCal})$ & $\begin{array}{c}0.013 \\
(0.075)\end{array}$ & & & 1834 & $\begin{array}{l}-0.014 \\
(0.090)\end{array}$ & & & 2444 \\
\hline $\log$ (Monthly non-food expenditure items) & $\begin{array}{l}-0.003 \\
(0.091)\end{array}$ & & & 1834 & $\begin{array}{c}-0.156^{* *} \\
(0.078)\end{array}$ & & & 2444 \\
\hline $\log ($ Reported income $)$ & $\begin{array}{l}-0.085 \\
(0.141)\end{array}$ & & & 1834 & $\begin{array}{l}-0.072 \\
(0.124)\end{array}$ & & & 2444 \\
\hline \multicolumn{9}{|l|}{ Panel C: Food Shortages } \\
\hline$\overline{\text { Food Shortage Index }}$ & $\begin{array}{l}-0.122 \\
(0.096)\end{array}$ & $\begin{array}{l}-0.291 \\
(0.200)\end{array}$ & $\begin{array}{c}-0.04 \\
(0.113)\end{array}$ & 5907 & $\begin{array}{l}-0.139 \\
(0.132)\end{array}$ & $\begin{array}{l}-0.022 \\
(0.176)\end{array}$ & $\begin{array}{l}-0.217 \\
(0.138)\end{array}$ & 6565 \\
\hline 1(Anticipate food shortage in January) & $\begin{array}{l}-0.018 \\
(0.077)\end{array}$ & $\begin{array}{l}-0.13 \\
(0.146)\end{array}$ & $\begin{array}{c}0.037 \\
(0.092)\end{array}$ & 5907 & $\begin{array}{l}-0.089 \\
(0.085)\end{array}$ & $\begin{array}{l}-0.046 \\
(0.117)\end{array}$ & $\begin{array}{l}-0.118 \\
(0.083)\end{array}$ & 6565 \\
\hline 1(Anticipate food shortage in April) & $\begin{array}{l}-0.012 \\
(0.032)\end{array}$ & $\begin{array}{l}-0.065 \\
(0.040)\end{array}$ & $\begin{array}{c}0.015 \\
(0.032)\end{array}$ & 5907 & $\begin{array}{c}-0.03 \\
(0.029)\end{array}$ & $\begin{array}{c}0 \\
(0.044)\end{array}$ & $\begin{array}{l}-0.051 \\
(0.036)\end{array}$ & 6565 \\
\hline 1(Anticipate food shortage in November) & $\begin{array}{l}-0.080^{*} \\
(0.048)\end{array}$ & $\begin{array}{l}-0.108 \\
(0.106)\end{array}$ & $\begin{array}{l}-0.067 \\
(0.062)\end{array}$ & 5907 & $\begin{array}{l}-0.056 \\
(0.069)\end{array}$ & $\begin{array}{c}0.052 \\
(0.111)\end{array}$ & $\begin{array}{l}-0.128^{*} \\
(0.076)\end{array}$ & 6565 \\
\hline 1(Lacked food last month) & $\begin{array}{l}-0.078 \\
(0.063)\end{array}$ & $\begin{array}{l}-0.180^{*} \\
(0.105)\end{array}$ & $\begin{array}{l}-0.028 \\
(0.063)\end{array}$ & 5907 & $\begin{array}{c}-0.05 \\
(0.070)\end{array}$ & $\begin{array}{l}-0.076 \\
(0.078)\end{array}$ & $\begin{array}{l}-0.032 \\
(0.084)\end{array}$ & 6565 \\
\hline \multicolumn{9}{|l|}{ Panel D: Health } \\
\hline Health Index & $\begin{array}{l}-0.016 \\
(0.072)\end{array}$ & $\begin{array}{c}0.13 \\
(0.087)\end{array}$ & $\begin{array}{l}-0.089 \\
(0.088)\end{array}$ & 5907 & $\begin{array}{l}-0.127 \\
(0.103)\end{array}$ & $\begin{array}{c}0.176 \\
(0.150)\end{array}$ & $\begin{array}{c}-0.331 * * * \\
(0.116)\end{array}$ & 6565 \\
\hline 1(Health expenditure shortages last month) & $\begin{array}{c}0.005 \\
(0.026)\end{array}$ & $\begin{array}{l}-0.054 \\
(0.040)\end{array}$ & $\begin{array}{c}0.035 \\
(0.027)\end{array}$ & 5907 & $\begin{array}{l}0.055^{*} \\
(0.032)\end{array}$ & $\begin{array}{c}-0.01 \\
(0.041)\end{array}$ & $\begin{array}{c}0.100 * * * \\
(0.038)\end{array}$ & 6565 \\
\hline Number of sick days & $\begin{array}{c}0.046 \\
(0.056)\end{array}$ & $\begin{array}{l}-0.032 \\
(0.049)\end{array}$ & $\begin{array}{c}0.087 \\
(0.077)\end{array}$ & 5907 & $\begin{array}{c}0.055 \\
(0.092)\end{array}$ & $\begin{array}{l}-0.154 \\
(0.143)\end{array}$ & $\begin{array}{l}0.196^{*} \\
(0.104)\end{array}$ & 6565 \\
\hline Number of sick household members & $\begin{array}{l}-0.003 \\
(0.005)\end{array}$ & $\begin{array}{l}-0.009 \\
(0.008)\end{array}$ & $\begin{array}{c}0.001 \\
(0.005)\end{array}$ & 5907 & $\begin{array}{c}0.007 \\
(0.006)\end{array}$ & $\begin{array}{l}-0.011 \\
(0.008)\end{array}$ & $\begin{array}{c}0.018 * * * \\
(0.007)\end{array}$ & 6565 \\
\hline
\end{tabular}

$* \mathrm{p}<0.10, * * \mathrm{p}<0.05, * * * \mathrm{p}<0.01$

Notes-This table replicates Table 2, but drops all observations with missing values. 
Table A3: Actual differences

\begin{tabular}{lcc}
\hline Treatment: & Storage & Credit \\
\cline { 2 - 3 } & $(1)$ & $(2)$ \\
\hline Seasonal Gap Index & 0.010 & 0.047 \\
& $(0.188)$ & $(0.141)$ \\
$\log ($ Staple consumed, kCal) & $0.252^{*}$ & 0.256 \\
& $(0.147)$ & $(0.158)$ \\
$\log$ (Monthly non-food expenditure items) & 0.047 & -0.043 \\
& $(0.223)$ & $(0.190)$ \\
$\log ($ Reported income $)$ & -0.414 & -0.087 \\
& $(0.358)$ & $(0.225)$ \\
\hline
\end{tabular}

$* \mathrm{p}<0.10, * * \mathrm{p}<0.05, * * * \mathrm{p}<0.01$

Notes-This table repeats the regressions in Panel B of Table 2, except using actual differences instead of absolute differences. For the seasonal gap index, the estimation sample for storage includes 1834 observations and the estimation sample for credit includes 2444 observations. 
Table A4: IV for Storage Treatment, by Baseline Retention Rate

\begin{tabular}{|c|c|c|c|c|c|c|c|}
\hline \multirow[t]{2}{*}{ Season: } & \multirow{2}{*}{$\begin{array}{l}\mathrm{N}(\text { All }) \\
\text { [p-value] }\end{array}$} & \multicolumn{2}{|c|}{ All } & \multicolumn{2}{|c|}{ Lean } & \multicolumn{2}{|c|}{ Harvest } \\
\hline & & (1) & (2) & (3) & (4) & (5) & (6) \\
\hline \multicolumn{8}{|l|}{ Panel A: Consumption and Income } \\
\hline$\overline{\text { Consumption and Income Index }}$ & 5494 & 0.088 & $(0.113)$ & 0.070 & $(0.127)$ & 0.098 & $(0.119)$ \\
\hline Consumption and Income Index_LG & {$[0.00]$} & $0.344 * * *$ & $(0.127)$ & $0.276 *$ & $(0.148)$ & $0.379 * * *$ & $(0.136)$ \\
\hline Log(Staple consumed, $\mathrm{kCal})$ & 5583 & -0.056 & $(0.069)$ & -0.099 & $(0.104)$ & -0.035 & $(0.078)$ \\
\hline Log(Staple consumed, $\mathrm{kCal}) \_L G$ & {$[0.20]$} & $0.163 *$ & $(0.083)$ & 0.178 & $(0.113)$ & $0.156^{*}$ & $(0.094)$ \\
\hline Log(Non-food expenditure, in $1000 \mathrm{Rp})$ & 5603 & 0.151 & $(0.135)$ & 0.139 & $(0.165)$ & 0.158 & $(0.139)$ \\
\hline Log(Non-food expenditure, in 1000 Rp)_LG & {$[0.00]$} & $0.321 * *$ & $(0.148)$ & $0.349 * *$ & $(0.163)$ & $0.306^{*}$ & $(0.159)$ \\
\hline Log(Reported income) & 5515 & 0.259 & $(0.265)$ & 0.327 & $(0.268)$ & 0.229 & $(0.344)$ \\
\hline Log(Reported income)_LG & {$[0.06]$} & $0.613 *$ & $(0.313)$ & 0.251 & $(0.308)$ & $0.795 * *$ & $(0.392)$ \\
\hline \multicolumn{8}{|l|}{ Panel B: Seasonal Differences, IHarvest - Leanl } \\
\hline Seasonal Gap Index & 1721 & 0.037 & $(0.086)$ & & & & \\
\hline Seasonal Gap Index_LG & {$[0.25]$} & -0.148 & $(0.107)$ & & & & \\
\hline Log(Staple consumed, $\mathrm{kCal})$ & 1788 & 0.067 & $(0.070)$ & & & & \\
\hline Log(Staple consumed, $\mathrm{kCal}) \_L G$ & [0.90] & -0.080 & $(0.090)$ & & & & \\
\hline Log(Monthly non-food expenditure items) & 1801 & 0.001 & $(0.091)$ & & & & \\
\hline Log(Monthly non-food expenditure items)_LG & [0.97] & 0.003 & $(0.112)$ & & & & \\
\hline Log(Reported income) & 1735 & 0.003 & $(0.146)$ & & & & \\
\hline Log(Reported income)_LG & {$[0.22]$} & -0.246 & $(0.202)$ & & & & \\
\hline \multicolumn{8}{|l|}{ Panel C: Food Shortages } \\
\hline Food Shortage Index & 5916 & -0.083 & $(0.090)$ & -0.197 & $(0.181)$ & -0.026 & $(0.107)$ \\
\hline Food Shortage Index_LG & {$[0.11]$} & -0.122 & $(0.113)$ & -0.206 & $(0.166)$ & -0.080 & $(0.151)$ \\
\hline 1(Anticipate food shortage in January) & 5916 & -0.023 & $(0.066)$ & -0.105 & $(0.127)$ & 0.019 & $(0.082)$ \\
\hline 1(Anticipate food shortage in January)_LG & {$[0.67]$} & -0.021 & $(0.085)$ & -0.048 & $(0.120)$ & -0.008 & $(0.107)$ \\
\hline 1(Anticipate food shortage in April) & 5916 & -0.018 & $(0.030)$ & -0.052 & $(0.040)$ & -0.002 & $(0.033)$ \\
\hline 1(Anticipate food shortage in April)_LG & {$[0.76]$} & 0.006 & $(0.042)$ & -0.029 & $(0.062)$ & 0.023 & $(0.041)$ \\
\hline 1(Anticipate food shortage in November) & 5916 & -0.021 & $(0.043)$ & -0.020 & $(0.100)$ & -0.021 & $(0.056)$ \\
\hline 1(Anticipate food shortage in November)_LG & {$[0.02]$} & $-0.135^{* *}$ & $(0.065)$ & $-0.193 * *$ & $(0.090)$ & -0.105 & $(0.095)$ \\
\hline 1(Lacked food last month) & 5916 & -0.084 & $(0.067)$ & $-0.180 *$ & $(0.094)$ & -0.036 & $(0.074)$ \\
\hline 1(Lacked food last month)_LG & {$[0.18]$} & -0.004 & $(0.063)$ & -0.006 & $(0.105)$ & -0.003 & $(0.067)$ \\
\hline \multicolumn{8}{|l|}{$\underline{\text { Panel D: Health }}$} \\
\hline Health Index & 5916 & 0.041 & $(0.078)$ & $0.225 * *$ & $(0.094)$ & -0.050 & $(0.097)$ \\
\hline Health Index_LG & {$[0.58]$} & -0.095 & $(0.108)$ & $-0.198 * *$ & $(0.096)$ & -0.044 & $(0.144)$ \\
\hline 1(Health expenditure shortages last month) & 5916 & -0.007 & $(0.030)$ & -0.048 & $(0.047)$ & 0.014 & $(0.032)$ \\
\hline 1(Health expenditure shortages last month)_LG & [0.37] & 0.031 & $(0.030)$ & -0.009 & $(0.049)$ & 0.051 & $(0.039)$ \\
\hline Number of sick days & 5916 & 0.019 & $(0.059)$ & $-0.088^{*}$ & $(0.050)$ & 0.073 & $(0.080)$ \\
\hline Number of sick days_LG & {$[0.73]$} & 0.012 & $(0.105)$ & 0.098 & $(0.060)$ & -0.031 & $(0.148)$ \\
\hline Number of sick household members & 5916 & -0.007 & $(0.006)$ & $-0.019 * *$ & $(0.007)$ & -0.001 & $(0.007)$ \\
\hline Number of sick household members_LG & {$[0.70]$} & 0.009 & $(0.007)$ & $0.022 * * *$ & $(0.007)$ & 0.002 & $(0.009)$ \\
\hline
\end{tabular}

$* \mathrm{p}<0.1, * * \mathrm{p}<0.05, * * * \mathrm{p}<0.01$

Notes-This table reports heterogeneous treatment effect regressions by the baseline retention rate of each household. Each regression corresponds to an instrumental variable regression where the two main independent variables are (i) a take-up dummy instrumented with the treatment assignment (ii) the take-up dummy interacted with a dummy for below median retention rate. Each group of four cells above reports the coefficient estimate and standard error for these two independent variables in a regression. The dependent variable for each regression is noted in the table. All regressions include district (kabupaten) fixed effects because assignment of treatment was within each district. Standard errors reported in the parentheses. All standard errors are clustered at the village level. Columns 1-2 use all the post treatment data (rounds 4 to 6). Columns 3-4 only include lean season data (round 5). Columns 5-6 only include harvest season data (rounds 4 and 6). N(All) reports the sample size for the regression using all seasons (columns 1 and 2). P-values (in brackets) correspond to a test that the sum of the take-up dummy and the interaction is equal to zero, for the regression with all seasons. 
Table A5: IV for Storage Treatment for Alfa Omega and TLM Districts

\begin{tabular}{|c|c|c|c|c|c|c|}
\hline \multirow{3}{*}{$\begin{array}{l}\text { NGO: } \\
\text { Season: }\end{array}$} & \multicolumn{3}{|c|}{ Alfa Omega Districts } & \multicolumn{3}{|c|}{ TLM Districts } \\
\hline & All & Lean & Harvest & All & Lean & Harves \\
\hline & (1) & (2) & (3) & $(4)$ & $(5)$ & (6) \\
\hline \multicolumn{7}{|l|}{ Panel A: Consumption and Income } \\
\hline$\overline{\text { Consumption and Income Index }}$ & $\begin{array}{c}0.201 * * \\
(0.103)\end{array}$ & $\begin{array}{c}0.173 \\
(0.170)\end{array}$ & $\begin{array}{c}0.216^{* * * *} \\
(0.083)\end{array}$ & $\begin{array}{c}0.307 \\
(0.223)\end{array}$ & $\begin{array}{c}0.209 \\
(0.227)\end{array}$ & $\begin{array}{c}0.359 \\
(0.244)\end{array}$ \\
\hline Log(Staple consumed, $\mathrm{kCal})$ & $\begin{array}{c}0.045 \\
(0.069)\end{array}$ & $\begin{array}{l}-0.026 \\
(0.113)\end{array}$ & $\begin{array}{c}0.079 \\
(0.068)\end{array}$ & $\begin{array}{l}-0.028 \\
(0.127)\end{array}$ & $\begin{array}{l}-0.044 \\
(0.189)\end{array}$ & $\begin{array}{l}-0.016 \\
(0.135)\end{array}$ \\
\hline $\log$ (Non-food expenditure, in $1000 \mathrm{Rp}$ ) & $\begin{array}{c}0.285^{* * *} \\
(0.142)\end{array}$ & $\begin{array}{c}0.309 \\
(0.236)\end{array}$ & $\begin{array}{c}0.275^{* *} \\
(0.129)\end{array}$ & $\begin{array}{c}0.378 \\
(0.255)\end{array}$ & $\begin{array}{c}0.313 \\
(0.289)\end{array}$ & $\begin{array}{c}0.410 \\
(0.262)\end{array}$ \\
\hline $\log ($ Reported income $)$ & $\begin{array}{c}0.214 \\
(0.216)\end{array}$ & $\begin{array}{c}0.294 \\
(0.333)\end{array}$ & $\begin{array}{c}0.175 \\
(0.210)\end{array}$ & $\begin{array}{c}0.923 \\
(0.729)\end{array}$ & $\begin{array}{c}0.615 \\
(0.444)\end{array}$ & $\begin{array}{c}1.085 \\
(1.027)\end{array}$ \\
\hline \multicolumn{7}{|l|}{ Panel B: Seasonal Differences, |Harvest - Lean| } \\
\hline Seasonal Gap Index & $\begin{array}{c}-0.035 \\
(0.110)\end{array}$ & & & $\begin{array}{l}-0.017 \\
(0.104)\end{array}$ & & \\
\hline Log(Staple consumed, $\mathrm{kCal})$ & $\begin{array}{l}-0.049 \\
(0.077)\end{array}$ & & & $\begin{array}{c}0.105 \\
(0.138)\end{array}$ & & \\
\hline $\log ($ Monthly non-food expenditure items) & $\begin{array}{c}0.086 \\
(0.138)\end{array}$ & & & $\begin{array}{l}-0.103 \\
(0.110)\end{array}$ & & \\
\hline $\log ($ Reported income $)$ & $\begin{array}{l}-0.105 \\
(0.134)\end{array}$ & & & $\begin{array}{l}-0.046 \\
(0.287)\end{array}$ & & \\
\hline \multicolumn{7}{|l|}{ Panel C: Food Shortages } \\
\hline$\overline{\text { Food Shortage Index }}$ & $\begin{array}{l}-0.134 \\
(0.102)\end{array}$ & $\begin{array}{l}-0.360 \\
(0.284)\end{array}$ & $\begin{array}{l}-0.021 \\
(0.110)\end{array}$ & $\begin{array}{l}-0.147 \\
(0.181)\end{array}$ & $\begin{array}{l}-0.230 \\
(0.246)\end{array}$ & $\begin{array}{l}-0.105 \\
(0.226)\end{array}$ \\
\hline 1(Anticipate food shortage in January) & $\begin{array}{c}0.007 \\
(0.088)\end{array}$ & $\begin{array}{l}-0.214 \\
(0.199)\end{array}$ & $\begin{array}{c}0.117 \\
(0.108)\end{array}$ & $\begin{array}{l}-0.088 \\
(0.135)\end{array}$ & $\begin{array}{l}-0.036 \\
(0.190)\end{array}$ & $\begin{array}{l}-0.114 \\
(0.155)\end{array}$ \\
\hline 1(Anticipate food shortage in April) & $\begin{array}{l}-0.033 \\
(0.042)\end{array}$ & $\begin{array}{l}-0.070 \\
(0.051)\end{array}$ & $\begin{array}{l}-0.015 \\
(0.041)\end{array}$ & $\begin{array}{c}0.016 \\
(0.045)\end{array}$ & $\begin{array}{c}-0.052 \\
(0.059)\end{array}$ & $\begin{array}{c}0.050 \\
(0.047)\end{array}$ \\
\hline 1(Anticipate food shortage in November) & $\begin{array}{l}-0.057 \\
(0.051)\end{array}$ & $\begin{array}{l}-0.108 \\
(0.160)\end{array}$ & $\begin{array}{l}-0.031 \\
(0.059)\end{array}$ & $\begin{array}{l}-0.134 \\
(0.089)\end{array}$ & $\begin{array}{l}-0.143 \\
(0.120)\end{array}$ & $\begin{array}{l}-0.129 \\
(0.123)\end{array}$ \\
\hline 1(Lacked food last month) & $\begin{array}{l}-0.143^{*} \\
(0.077)\end{array}$ & $\begin{array}{l}-0.216 \\
(0.133)\end{array}$ & $\begin{array}{l}-0.107 \\
(0.070)\end{array}$ & $\begin{array}{c}0.009 \\
(0.096)\end{array}$ & $\begin{array}{l}-0.124 \\
(0.148)\end{array}$ & $\begin{array}{c}0.076 \\
(0.110)\end{array}$ \\
\hline \multicolumn{7}{|l|}{ Panel D: Health } \\
\hline Health Index & $\begin{array}{l}-0.116 \\
(0.107)\end{array}$ & $\begin{array}{c}0.107 \\
(0.121)\end{array}$ & $\begin{array}{l}-0.228^{*} \\
(0.131)\end{array}$ & $\begin{array}{c}0.159 \\
(0.100)\end{array}$ & $\begin{array}{c}0.172 \\
(0.112)\end{array}$ & $\begin{array}{c}0.153 \\
(0.123)\end{array}$ \\
\hline 1(Health expenditure shortages last month) & $\begin{array}{c}0.032 \\
(0.035)\end{array}$ & $\begin{array}{l}-0.045 \\
(0.057)\end{array}$ & $\begin{array}{c}0.070 * * \\
(0.034)\end{array}$ & $\begin{array}{c}-0.032 \\
(0.039)\end{array}$ & $\begin{array}{l}-0.064 \\
(0.044)\end{array}$ & $\begin{array}{l}-0.016 \\
(0.044)\end{array}$ \\
\hline Number of sick days & $\begin{array}{c}0.098 \\
(0.089)\end{array}$ & $\begin{array}{l}-0.054 \\
(0.060)\end{array}$ & $\begin{array}{c}0.174 \\
(0.125)\end{array}$ & $\begin{array}{l}-0.057 \\
(0.069)\end{array}$ & $\begin{array}{l}-0.006 \\
(0.073)\end{array}$ & $\begin{array}{l}-0.082 \\
(0.092)\end{array}$ \\
\hline Number of sick household members & $\begin{array}{c}0.004 \\
(0.006)\end{array}$ & $\begin{array}{l}-0.005 \\
(0.010)\end{array}$ & $\begin{array}{c}0.009 \\
(0.007)\end{array}$ & $\begin{array}{l}-0.014 * \\
(0.008)\end{array}$ & $\begin{array}{l}-0.017 \\
(0.013)\end{array}$ & $\begin{array}{l}-0.013 \\
(0.009)\end{array}$ \\
\hline
\end{tabular}

$* \mathrm{p}<0.1, * * \mathrm{p}<0.05, * * * \mathrm{p}<0.01$

Notes-This table repeats IV regressions for storage reported in columns 1 to 3 in Table 2, but does so separately for Alfa Omega villages (columns 1 to 3 in this table) and TLM villages (columns 4 to 6 in this table). 
Table A6: IV for Credit Treatment for Alfa Omega and TLM Districts

\begin{tabular}{|c|c|c|c|c|c|c|}
\hline \multirow{3}{*}{$\begin{array}{l}\text { NGO: } \\
\text { Season: }\end{array}$} & \multicolumn{3}{|c|}{ Alfa Omega Districts } & \multicolumn{3}{|c|}{ TLM Districts } \\
\hline & All & Lean & Harvest & All & Lean & Harvest \\
\hline & (1) & $(2)$ & (3) & (4) & $(5)$ & (6) \\
\hline \multicolumn{7}{|l|}{ Panel A: Consumption and Income } \\
\hline$\overline{\text { Consumption and Income Index }}$ & $\begin{array}{l}0.153^{*} \\
(0.090)\end{array}$ & $\begin{array}{c}0.016 \\
(0.118)\end{array}$ & $\begin{array}{c}0.246 * * \\
(0.101)\end{array}$ & $\begin{array}{c}0.181 \\
(0.230)\end{array}$ & $\begin{array}{c}0.008 \\
(0.228)\end{array}$ & $\begin{array}{c}0.298 \\
(0.280)\end{array}$ \\
\hline Log(Staple consumed, kCal) & $\begin{array}{c}0.057 \\
(0.075)\end{array}$ & $\begin{array}{l}-0.044 \\
(0.088)\end{array}$ & $\begin{array}{c}0.125 \\
(0.092)\end{array}$ & $\begin{array}{c}0.064 \\
(0.182)\end{array}$ & $\begin{array}{l}-0.100 \\
(0.220)\end{array}$ & $\begin{array}{c}0.176 \\
(0.237)\end{array}$ \\
\hline $\log ($ Non-food expenditure, in $1000 \mathrm{Rp})$ & $\begin{array}{c}0.129 \\
(0.128)\end{array}$ & $\begin{array}{l}-0.003 \\
(0.157)\end{array}$ & $\begin{array}{c}0.218 \\
(0.147)\end{array}$ & $\begin{array}{c}0.106 \\
(0.241)\end{array}$ & $\begin{array}{l}-0.032 \\
(0.277)\end{array}$ & $\begin{array}{c}0.195 \\
(0.262)\end{array}$ \\
\hline $\log ($ Reported income $)$ & $\begin{array}{c}0.390^{* *} \\
(0.152)\end{array}$ & $\begin{array}{c}0.287 \\
(0.239)\end{array}$ & $\begin{array}{c}0.459^{* * * *} \\
(0.150)\end{array}$ & $\begin{array}{c}0.772 \\
(0.581)\end{array}$ & $\begin{array}{c}0.497 \\
(0.485)\end{array}$ & $\begin{array}{c}0.966 \\
(0.840)\end{array}$ \\
\hline \multicolumn{7}{|c|}{ Panel B: Seasonal Differences, IHarvest - Leanl } \\
\hline Seasonal Gap Index & $\begin{array}{c}-0.169 * * \\
(0.085)\end{array}$ & & & $\begin{array}{l}-0.087 \\
(0.169)\end{array}$ & & \\
\hline Log(Staple consumed, kCal) & $\begin{array}{l}-0.024 \\
(0.060)\end{array}$ & & & $\begin{array}{c}0.043 \\
(0.206)\end{array}$ & & \\
\hline Log(Monthly non-food expenditure items) & $\begin{array}{l}-0.135 \\
(0.093)\end{array}$ & & & $\begin{array}{l}-0.198 \\
(0.139)\end{array}$ & & \\
\hline $\log ($ Reported income $)$ & $\begin{array}{l}-0.175 \\
(0.131)\end{array}$ & & & $\begin{array}{c}0.120 \\
(0.249)\end{array}$ & & \\
\hline \multicolumn{7}{|l|}{ Panel C: Food Shortages } \\
\hline Food Shortage Index & $\begin{array}{c}-0.259^{*} \\
(0.135)\end{array}$ & $\begin{array}{l}-0.159 \\
(0.196)\end{array}$ & $\begin{array}{c}-0.326^{* *} \\
(0.142)\end{array}$ & $\begin{array}{c}0.058 \\
(0.246)\end{array}$ & $\begin{array}{c}0.198 \\
(0.301)\end{array}$ & $\begin{array}{l}-0.036 \\
(0.267)\end{array}$ \\
\hline 1(Anticipate food shortage in January) & $\begin{array}{c}-0.109 \\
(0.098)\end{array}$ & $\begin{array}{l}-0.111 \\
(0.139)\end{array}$ & $\begin{array}{c}-0.107 \\
(0.092)\end{array}$ & $\begin{array}{l}-0.080 \\
(0.143)\end{array}$ & $\begin{array}{c}0.057 \\
(0.190)\end{array}$ & $\begin{array}{l}-0.171 \\
(0.143)\end{array}$ \\
\hline 1(Anticipate food shortage in April) & $\begin{array}{c}-0.065^{* *} \\
(0.033)\end{array}$ & $\begin{array}{l}-0.020 \\
(0.048)\end{array}$ & $\begin{array}{c}-0.096 * * \\
(0.037)\end{array}$ & $\begin{array}{c}0.042 \\
(0.055)\end{array}$ & $\begin{array}{c}0.052 \\
(0.085)\end{array}$ & $\begin{array}{c}0.035 \\
(0.075)\end{array}$ \\
\hline 1(Anticipate food shortage in November) & $\begin{array}{c}-0.113 \\
(0.072)\end{array}$ & $\begin{array}{l}-0.040 \\
(0.132)\end{array}$ & $\begin{array}{c}-0.163 * * \\
(0.081)\end{array}$ & $\begin{array}{c}0.038 \\
(0.127)\end{array}$ & $\begin{array}{c}0.196 \\
(0.179)\end{array}$ & $\begin{array}{l}-0.067 \\
(0.141)\end{array}$ \\
\hline 1(Lacked food last month) & $\begin{array}{l}-0.132 * \\
(0.078)\end{array}$ & $\begin{array}{l}-0.101 \\
(0.087)\end{array}$ & $\begin{array}{c}-0.152 \\
(0.095)\end{array}$ & $\begin{array}{c}0.096 \\
(0.124)\end{array}$ & $\begin{array}{l}-0.048 \\
(0.133)\end{array}$ & $\begin{array}{c}0.191 \\
(0.155)\end{array}$ \\
\hline \multicolumn{7}{|l|}{ Panel D: Health } \\
\hline Health Index & $\begin{array}{l}-0.112 \\
(0.125)\end{array}$ & $\begin{array}{c}0.243 \\
(0.187)\end{array}$ & $\begin{array}{c}-0.349 * * \\
(0.144)\end{array}$ & $\begin{array}{l}-0.137 \\
(0.176)\end{array}$ & $\begin{array}{c}0.108 \\
(0.242)\end{array}$ & $\begin{array}{l}-0.301 \\
(0.191)\end{array}$ \\
\hline 1(Health expenditure shortages last month) & $\begin{array}{c}0.044 \\
(0.034)\end{array}$ & $\begin{array}{c}-0.002 \\
(0.039)\end{array}$ & $\begin{array}{l}0.074 * \\
(0.042)\end{array}$ & $\begin{array}{c}0.077 \\
(0.060)\end{array}$ & $\begin{array}{l}-0.035 \\
(0.080)\end{array}$ & $\begin{array}{c}0.151^{* *} \\
(0.068)\end{array}$ \\
\hline Number of sick days & $\begin{array}{c}0.069 \\
(0.122)\end{array}$ & $\begin{array}{l}-0.235 \\
(0.194)\end{array}$ & $\begin{array}{c}0.272 * * \\
(0.137)\end{array}$ & $\begin{array}{c}0.015 \\
(0.136)\end{array}$ & $\begin{array}{l}-0.049 \\
(0.203)\end{array}$ & $\begin{array}{c}0.057 \\
(0.150)\end{array}$ \\
\hline Number of sick household members & $\begin{array}{c}0.005 \\
(0.007)\end{array}$ & $\begin{array}{l}-0.015 \\
(0.010)\end{array}$ & $\begin{array}{c}0.018 * * \\
(0.008)\end{array}$ & $\begin{array}{c}0.009 \\
(0.010)\end{array}$ & $\begin{array}{l}-0.007 \\
(0.013)\end{array}$ & $\begin{array}{l}0.019 * \\
(0.012)\end{array}$ \\
\hline
\end{tabular}

$* \mathrm{p}<0.1, * * \mathrm{p}<0.05, * * * \mathrm{p}<0.01$

Notes-This table repeats IV regressions for credit reported in columns 5 to 7 in Table 2, but does so separately for Alfa Omega villages (columns 1 to 3 in this table) and TLM villages (columns 4 to 6 in this table). 